National Water-Quality Assessment Program

\title{
Numerical Model Simulations of Nitrate Concentrations in Groundwater Using Various Nitrogen Input Scenarios, Mid-Snake Region, South-Central Idaho
}

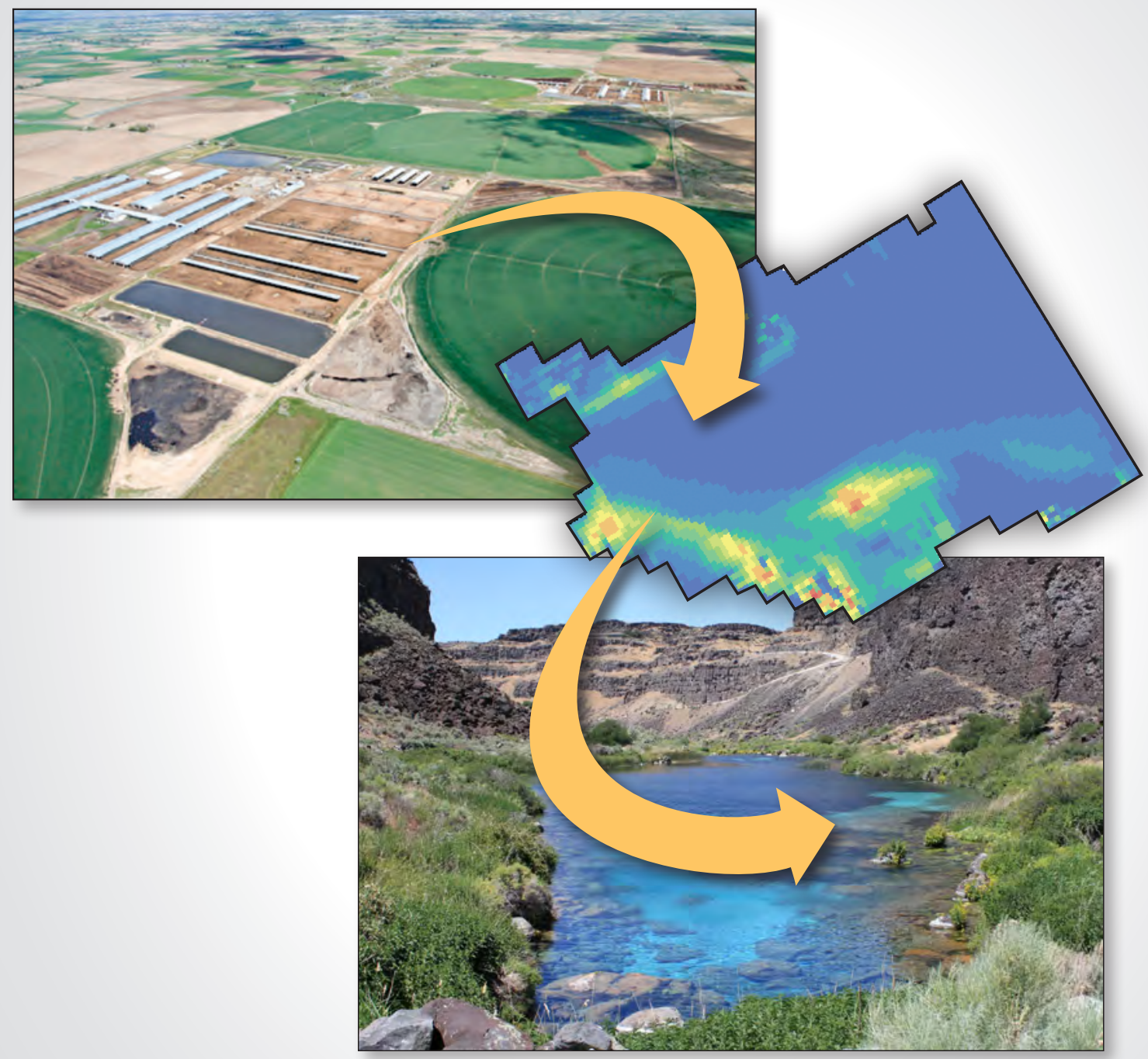

Scientific Investigations Report 2012-5237 


\section{Cover:}

Top photograph:

Photograph copyright Kestrel Aerial Services, Inc., (Cwww.kestrelaerial.com, used with permission.

Model image: Simulated nitrate concentrations in groundwater in 2048 from linearly projected nitrogen input.

Bottom photograph: Blue Lakes Spring. Photograph by Kenneth Skinner, U.S.

Geological Survey, Idaho, 2005. 


\section{Numerical Model Simulations of Nitrate Concentrations in Groundwater Using Various Nitrogen Input Scenarios, Mid-Snake Region, South-Central Idaho}

By Kenneth D. Skinner and Michael G. Rupert

National Water-Quality Assessment Program

Scientific Investigations Report 2012-5237 


\title{
U.S. Department of the Interior \\ KEN SALAZAR, Secretary \\ U.S. Geological Survey \\ Marcia K. McNutt, Director
}

\author{
U.S. Geological Survey, Reston, Virginia: 2012
}

For more information on the USGS - the Federal source for science about the Earth, its natural and living resources, natural hazards, and the environment, visit http://www.usgs.gov or call 1-888-ASK-USGS.

For an overview of USGS information products, including maps, imagery, and publications, visit http://www.usgs. gov/pubprod

To order this and other USGS information products, visit http://store.usgs.gov

Any use of trade, product, or firm names is for descriptive purposes only and does not imply endorsement by the U.S. Government.

Although this report is in the public domain, permission must be secured from the individual copyright owners to reproduce any copyrighted materials contained within this report.

Suggested citation:

Skinner, K.D., and Rupert, M.G., 2012, Numerical model simulations of nitrate concentrations in groundwater using various nitrogen input scenarios, mid-Snake region, south-central Idaho: U.S. Geological Survey Scientific Investigations Report 2012-5237, 30 p. 


\section{Foreword}

The U.S. Geological Survey (USGS) is committed to providing the Nation with reliable scientific information that helps to enhance and protect the overall quality of life and that facilitates effective management of water, biological, energy, and mineral resources (http://www.usgs.gov/). Information on the Nation's water resources is critical to ensuring long-term availability of water that is safe for drinking and recreation and is suitable for industry, irrigation, and fish and wildlife. Population growth and increasing demands for water make the availability of that water, measured in terms of quantity and quality, even more essential to the long-term sustainability of our communities and ecosystems.

The USGS implemented the National Water-Quality Assessment (NAWQA) Program in 1991 to support national, regional, State, and local information needs and decisions related to water-quality management and policy (http://water.usgs.gov/nawqa). The NAWQA Program is designed to answer: What is the quality of our Nation's streams and groundwater? How are conditions changing over time? How do natural features and human activities affect the quality of streams and groundwater, and where are those effects most pronounced? By combining information on water chemistry, physical characteristics, stream habitat, and aquatic life, the NAWQA Program aims to provide science-based insights for current and emerging water issues and priorities. From 1991 to 2001, the NAWQA Program completed interdisciplinary assessments and established a baseline understanding of water-quality conditions in 51 of the Nation's river basins and aquifers, referred to as Study Units (http://water.usgs.gov/nawqa/studies/study_units.html).

National and regional assessments are ongoing in the second decade (2001-2012) of the NAWQA Program as 42 of the 51 Study Units are selectively reassessed. These assessments extend the findings in the Study Units by determining water-quality status and trends at sites that have been consistently monitored for more than a decade, and filling critical gaps in characterizing the quality of surface water and groundwater. For example, increased emphasis has been placed on assessing the quality of source water and finished water associated with many of the Nation's largest community water systems. During the second decade, NAWQA is addressing five national priority topics that build an understanding of how natural features and human activities affect water quality, and establish links between sources of contaminants, the transport of those contaminants through the hydrologic system, and the potential effects of contaminants on humans and aquatic ecosystems. Included are studies on the fate of agricultural chemicals, effects of urbanization on stream ecosystems, bioaccumulation of mercury in stream ecosystems, effects of nutrient enrichment on aquatic ecosystems, and transport of contaminants to public-supply wells. In addition, national syntheses of information on pesticides, volatile organic compounds (VOCs), nutrients, trace elements, and aquatic ecology are continuing.

The USGS aims to disseminate credible, timely, and relevant science information to address practical and effective water-resource management and strategies that protect and restore water quality. We hope this NAWQA publication will provide you with insights and information to meet your needs, and will foster increased citizen awareness and involvement in the protection and restoration of our Nation's waters.

The USGS recognizes that a national assessment by a single program cannot address all water-resource issues of interest. External coordination at all levels is critical for cost-effective management, regulation, and conservation of our Nation's water resources. The NAWQA Program, therefore, depends on advice and information from other agencies—Federal, State, regional, interstate, Tribal, and local—as well as nongovernmental organizations, industry, academia, and other stakeholder groups. Your assistance and suggestions are greatly appreciated.

\section{William H. Werkheiser, USGS Associate Director for Water}




\section{Contents}

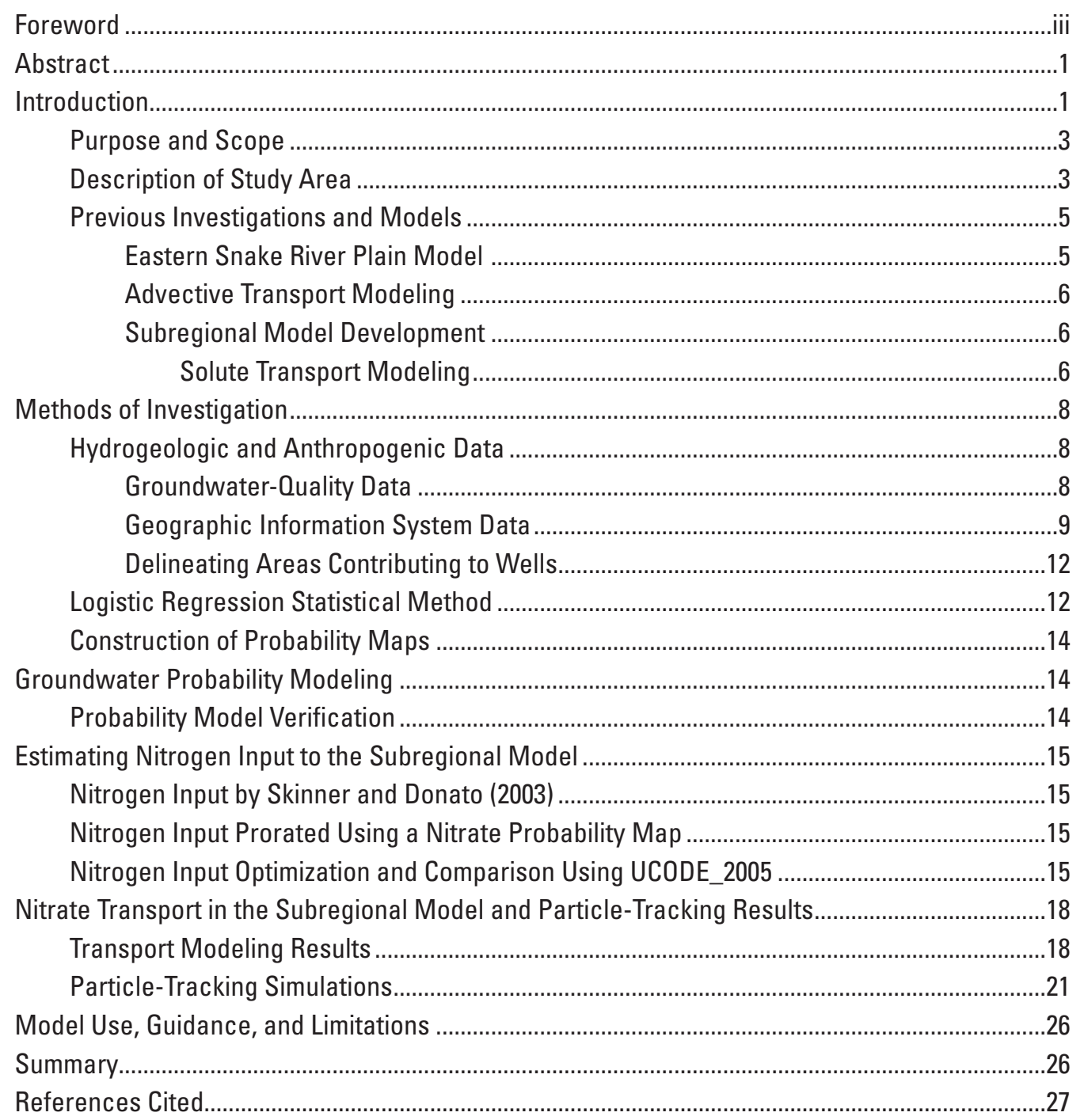




\section{Figures}

Figure 1. Map showing study area location, subregional model boundary, perched aquifer, and urbanized areas, mid-Snake region, south-central Idaho

Figure 2. Graph showing number of dairy cattle in the six mid-Snake counties, south-central Idaho

Figure 3. Graph showing increased nitrogen input in the past 50 years for fertilizer, and in the past 20 years for dairy and beef cattle, in six mid-Snake counties, south-central Idaho

Figure 4. Map showing extent of a subregional groundwater flow model of the mid-Snake region within the eastern Snake River Plain regional model, south-central Idaho

Figure 5. Map showing nitrate concentration data from groundwater used to create probability maps and to calibrate nitrogen input to the subregional model in the mid-Snake region, south-central Idaho

Figure 6. Conceptual diagram of wedge-shaped 90-degree buffer and circular buffer used to delineate areas that contribute recharge to a well 13

Figure 7. Deciles of risk plot showing the high correlation between percentage of actual nitrate detections and predicted probability of detecting nitrate concentrations groundwater, using 10 equal intervals

Figure 8. Graphs showing simulated nitrate concentrations and corresponding model residuals with linear regression trend lines indicating model bias in nitrogen input model updated from Skinner and Donato (2003) (SD) and nitrogen input model updated from Skinner and Donato (2003) and prorated with a probability model (SDPROB)

Figure 9. Graph showing nitrogen trends based on data collected during 1999-2008, south-central Idaho

Figure 10. Maps showing simulated nitrate concentrations in groundwater from linearly projected nitrogen input prorated by the probability map , eastern Snake River Plain aquifer, Idaho, 2008 and 2048

Figure 11. Map showing simulated nitrate concentrations in 2048 and time-series plots for three locations in the Snake River Plain aquifer, south-central Idaho

Figure 12. Map showing forward particle-tracking simulation starting in the easternmost column of model cells of the subregional model, south-central Idaho

Figure 13. Map showing forward particle-tracking simulation starting in the local perched aquifer of the subregional model, south-central Idaho

Figure 14. Map showing backward particle tracking simulation in the subregional model, south-central Idaho

Figure 15. Cross section and map showing the eastern Snake River Plain aquifer thins to the west toward the Thousand Springs area, south-central Idaho 


\section{Tables}

Table 1. Independent variables used to estimate probability of nitrate concentrations greater than 2 milligrams per liter in groundwater, mid-Snake region,

south-central Idaho

Table 2. Logistic regression model simulation, coefficients, and individual p-values of independent variables significantly related with the probability of detecting measured nitrate concentrations greater than 2 milligrams per liter in groundwater of the Mid-Snake Region, south-central Idaho

Table 3. Comparison of the effectiveness of two nitrogen input layers in the subregional model using UCODE_2005 statistical results

\section{Conversion Factors, Datums, and Abbreviations and Acronyms}

Conversion Factors

Inch/Pound to SI

\begin{tabular}{|c|c|c|}
\hline Multiply & By & To obtain \\
\hline \multicolumn{3}{|c|}{ Length } \\
\hline inch (in.) & 2.54 & centimeter $(\mathrm{cm})$ \\
\hline inch (in.) & 25.4 & millimeter (mm) \\
\hline foot (ft) & 0.3048 & meter (m) \\
\hline mile (mi) & 1.609 & kilometer (km) \\
\hline \multicolumn{3}{|c|}{ Area } \\
\hline square mile $\left(\mathrm{mi}^{2}\right)$ & 259.0 & hectare (ha) \\
\hline square mile $\left(\mathrm{mi}^{2}\right)$ & 2.590 & square kilometer $\left(\mathrm{km}^{2}\right)$ \\
\hline \multicolumn{3}{|c|}{ Flow rate } \\
\hline cubic foot per second $\left(\mathrm{ft}^{3} / \mathrm{s}\right)$ & 0.02832 & cubic meter per second $\left(\mathrm{m}^{3} / \mathrm{s}\right)$ \\
\hline gallon per minute (gal/min) & 0.06309 & liter per second (L/s) \\
\hline \multicolumn{3}{|c|}{ Mass } \\
\hline ton, short $(2,000 \mathrm{lb})$ & 0.9072 & megagram (Mg) \\
\hline \multicolumn{3}{|c|}{ Transmissivity* } \\
\hline foot squared per day $\left(\mathrm{ft}^{2} / \mathrm{d}\right)$ & 0.09290 & meter squared per day $\left(\mathrm{m}^{2} / \mathrm{d}\right)$ \\
\hline \multicolumn{3}{|c|}{ Application rate } \\
\hline pound per acre (lb/acre) & 1.121 & kilogram per hectare (kg/ha) \\
\hline \multicolumn{3}{|l|}{ SI to Inch/Pound } \\
\hline Multiply & By & To obtain \\
\hline \multicolumn{3}{|c|}{ Length } \\
\hline millimeter (mm) & 0.03937 & inch (in.) \\
\hline \multicolumn{3}{|c|}{ Flow rate } \\
\hline meter per day (m/d) & 3.281 & foot per day (ft/d) \\
\hline millimeter per year (mm/yr) & 0.03937 & inch per year (in/yr) \\
\hline \multicolumn{3}{|c|}{ Mass } \\
\hline kilogram (kg) & 2.205 & pound avoirdupois (lb) \\
\hline
\end{tabular}




\section{Conversion Factors, Datums, and Abbreviations and Acronyms-Continued}

Concentrations of chemical constituents in water are given in milligrams per liter ( $\mathrm{mg} / \mathrm{L})$.

*Transmissivity: The standard unit for transmissivity is cubic foot per day per square foot times foot of aquifer thickness [(ft $\left.\left.\mathrm{f}^{3} / \mathrm{d}\right) / \mathrm{ft}^{2}\right] \mathrm{ft}$. In this report, the mathematically reduced form, foot squared per day $\left(\mathrm{ft}^{2} / \mathrm{d}\right)$, is used for convenience.

Datums

Vertical coordinate information is referenced to the North American Vertical Datum of 1988 (NAVD 88).

Horizontal coordinate information is referenced to the North American Datum of 1983 (NAD 83). Elevation, as used in this report, refers to distance above the vertical datum.

Abbreviations and Acronyms

\begin{tabular}{ll}
\hline $\begin{array}{c}\text { Abbreviation } \\
\text { or acronym }\end{array}$ & \multicolumn{1}{c}{ Definition } \\
\hline Reclamation & Bureau of Reclamation \\
CEV & Calculated error variance \\
CSS & Composite scaled sensitivity \\
ESRP & Eastern Snake River Plain \\
GIS & Geographic information system \\
NAWQA & National Water-Quality Assessment Program \\
PRISM & Parameter-elevation Regression on Independent Slopes Model \\
RASA & Regional Aquifer-System Analysis \\
SD & Nitrogen input layer, from Skinner and Donato (2003) \\
SDPROB & Nitrogen input layer, updated from Skinner and Donato (2003), and prorated by \\
& a map showing probability of detecting elevated concentrations of nitrate \\
SE & Standard error \\
SSURGO & Soil Survey Geographic Database from the Natural Resources Conservation \\
& Service \\
USGS & U.S. Geological Survey \\
\hline
\end{tabular}




\title{
Numerical Model Simulations of Nitrate Concentrations in Groundwater Using Various Nitrogen Input Scenarios, Mid-Snake Region, South-Central Idaho
}

\author{
By Kenneth D. Skinner and Michael G. Rupert
}

\begin{abstract}
As part of the U.S. Geological Survey's National Water Quality Assessment (NAWQA) program nitrate transport in groundwater was modeled in the mid-Snake River region in south-central Idaho to project future concentrations of nitrate. Model simulation results indicated that nitrate concentrations would continue to increase over time, eventually exceeding the U.S. Environmental Protection Agency maximum contaminant level for drinking water of 10 milligrams per liter in some areas. A subregional groundwater model simulated the change of nitrate concentrations in groundwater over time in response to three nitrogen input scenarios: (1) nitrogen input fixed at 2008 levels; (2) nitrogen input increased from 2008 to 2028 using the same rate of increase as the average rate of increase during the previous 10 years (1998 through 2008); after 2028, nitrogen input is fixed at 2028 levels; and (3) nitrogen input related to agriculture completely halted, with only nitrogen input from precipitation remaining.

Scenarios 1 and 2 project that nitrate concentrations in groundwater continue to increase from 10 to 50 years beyond the year nitrogen input is fixed, depending on the location in the model area. Projected nitrate concentrations in groundwater increase by as much as $2-4$ milligrams per liter in many areas, with nitrate concentrations in some areas reaching 10 milligrams per liter. Scenario 3, although unrealistic, estimates how long (20-50 years) it would take nitrate in groundwater to return to background concentrations - the "flushing time" of the system.

The amount of nitrate concentration increase cannot be explained solely by differences in nitrogen input; in fact, some areas with the highest amount of nitrogen input have the lowest increase in nitrate concentration. The geometry of the aquifer and the pattern of regional groundwater flow through
\end{abstract}

the aquifer greatly influence nitrate concentrations. The aquifer thins toward discharge areas along the Snake River which forces upward convergence of good-quality regional groundwater that mixes with the nitrate-laden groundwater in the uppermost parts of the aquifer, which results in lowered nitrate concentrations.

A new method of inputting nitrogen to the subregional groundwater model was used that prorates nitrogen input by the probability of detecting nitrate concentrations greater than $2 \mathrm{mg} / \mathrm{L}$. The probability map is based on correlations with physical factors, and prorates an existing nitrogen input dataset providing an estimate of nitrogen flux to the water table that accounts for new factors such as soil properties. The effectiveness of this updated nitrogen input method was evaluated using the software UCODE_2005.

\section{Introduction}

Quality of groundwater is an ongoing concern in Idaho. In 1990, groundwater accounted for nearly 85 percent of the drinking water in the State; in 1995, it accounted for almost 95 percent (Solley and others, 1993, 1998). Previous studies in Idaho detected high concentrations of nitrate in many of the State's aquifers (Rupert, 1994; Crockett, 1995; Rupert and others, 1996). Previous studies also detected increasing concentrations of nitrate in a growing number of public- and domestic-use wells (Parliman and Young, 1987; Young and others, 1987a; Young and others, 1987b; Rupert, 1994; Clark and Ott, 1996; Rupert and others, 1996). The predominant sources of nitrate in groundwater throughout much of the State are inorganic fertilizer, cattle manure, and legume crops (Rupert, 1996). 
Increasing nitrate concentrations in groundwater are of particular concern in the mid-Snake region of south-central Idaho (fig. 1). The region is experiencing substantial growth in the dairy industry (fig. 2). Particularly large growth in dairy operations is occurring in Gooding, Jerome, and Twin Falls Counties (Idaho Agricultural Statistics Service, 1999; U.S. Department of Agriculture, 2010). These increased sources of nitrate to groundwater are in addition to sources from existing, long-term agricultural activities in the region.
Because of declining groundwater quality in parts of the mid-Snake region, the Idaho Department of Environmental Quality designated those areas as priority water-quality management areas and targeted them for further study and assistance to improve land-use planning, nitrogen monitoring, and nitrogen management. In response to these concerns, the U.S. Geological Survey (USGS) National Water Quality Assessment (NAWQA) program conducted this investigation in the mid-Snake region of south-central Idaho (fig. 1).
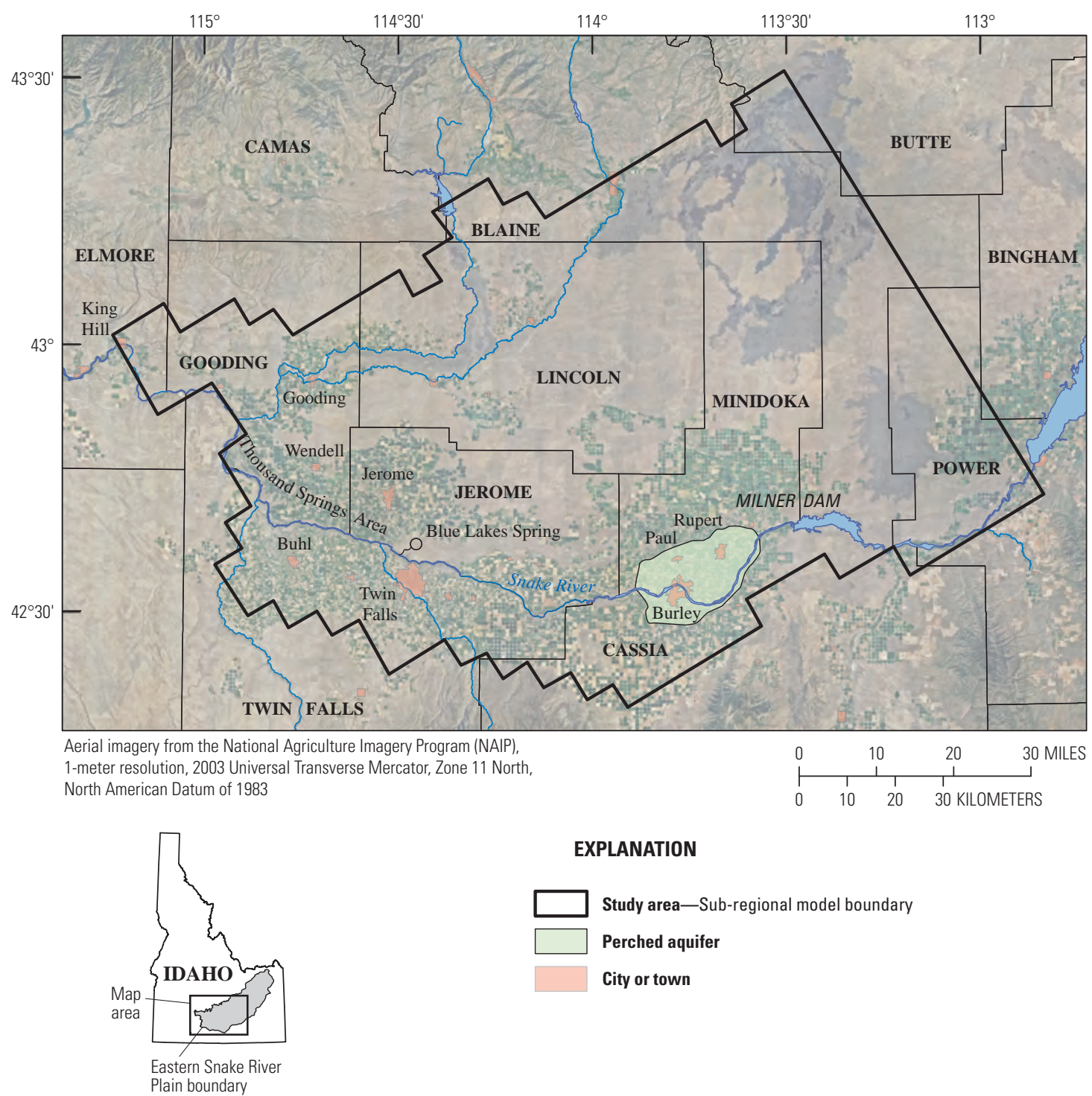

EXPLANATION

Study area-Sub-regional model boundary

Perched aquifer

City or town

Figure 1. Study area location, subregional model boundary, perched aquifer, and urbanized areas, mid-Snake region, south-central Idaho. 


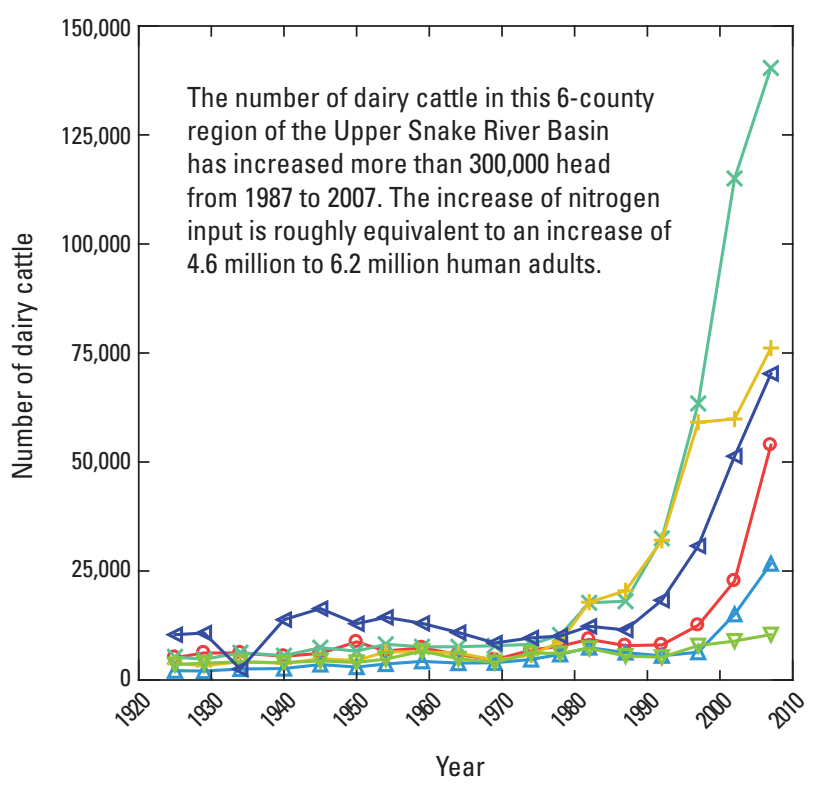

EXPLANATION

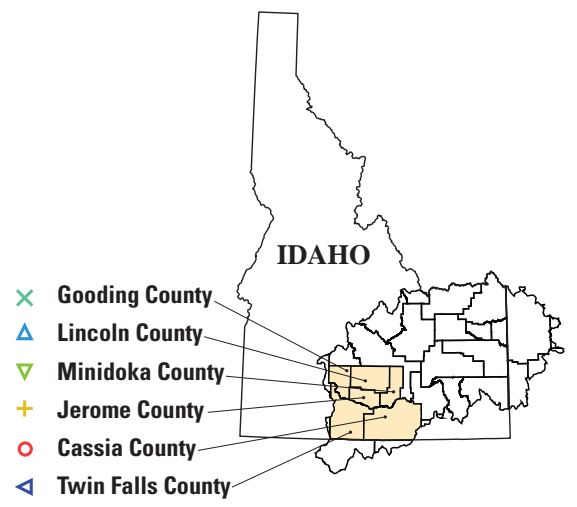

Figure 2. Number of dairy cattle in the six mid-Snake counties, south-central Idaho. Data from U.S. Department of Agriculture (2010).

\section{Purpose and Scope}

This report documents the modeling of nitrate concentrations in groundwater of the mid-Snake region of south-central Idaho (containing all or parts of Blaine, Bingham, Butte, Camas, Cassia, Elmore, Gooding, Jerome, Lincoln, Minidoka, Power, and Twin Falls Counties) using an existing three-dimensional groundwater-flow and transport model. The model simulates the change in nitrate concentrations in groundwater over time in response to three nitrogen input scenarios:
- Nitrogen input fixed at 2008 levels.

- Nitrogen input increased from 2008 to 2028 using the same rate of increase as the average rate of increase during the previous 10 years (1998 through 2008); after 2028, nitrogen input is fixed at 2028 levels.

- Nitrogen input related to agriculture completely halted, with only nitrogen input from precipitation remaining.

The study incorporated a new approach for estimating nitrogen input to the groundwater flow and transport model. A map estimating the probability of elevated nitrate concentrations in groundwater was used to prorate nitrogen input across the modeled area. The probability map was developed using logistic regression, which made correlations between measured nitrate concentrations in groundwater and cultural, hydrologic, land use, soil, and precipitation factors. The probability map then was used to prorate nitrogen input from the land surface to the water table. The groundwater-flow and transport model subsequently simulated transport of the nitrate from the water table, through the aquifer system, and finally to the discharge locations in the Thousand Springs area.

The scope of this report is limited to describing the simulation of the change in nitrate concentration in groundwater based on the observed and predicted changes in nitrogen input to the groundwater-flow and transport model. It was beyond the scope of this report to make any changes in, or to evaluate the effectiveness of, the existing three-dimensional groundwater-flow and transport model. For this report, the nitrogen was input to the groundwater-flow and transport model by using the auxiliary parameter in the MODFLOW WEL package (Harbaugh and McDonald, 1996a and 1996b). This was the only model parameter changed for this report; all other aspects of the groundwater-flow and transport model were left alone.

\section{Description of Study Area}

The study area (5,341 mi² in south-central Idaho; fig. 1) is the groundwater flow and transport model boundary of Clark and others (2006), referred to as the "subregional model" in this report. The model boundary includes Jerome and Minidoka Counties and parts of Blaine, Bingham, Butte, Camas, Cassia, Elmore, Gooding, Lincoln, Power, and Twin Falls Counties. The study area is in the downstream part of the eastern Snake River Plain. About 66 percent of the area is rangeland, 11 percent is flood-irrigated land, 21 percent is sprinkler-irrigated land, and the remaining 2 percent consists of several other land-use types. The area predominantly is semiarid; mean annual precipitation ranges from 8 to 18 in. Most agricultural land in the study area is near the Snake River, a major source of water for irrigation. 
Nitrogen input from fertilizers and cattle manure in the study area has increased dramatically during the past 50 years (fig. 3), and increasing nitrate (the most common form of dissolved nitrogen because of its high mobility) concentrations in groundwater reflect the increase in nitrogen input from fertilizer use and cattle manure. Even though nitrogen input from fertilizer is much greater than that from cattle manure, the number of dairy cattle in the study area has increased fivefold during the last 30 years, which is a source of increasing nitrate in groundwater (fig. 2). A significant amount of the cattle manure is used as fertilizer on surrounding fields, but excess nitrogen from the cattle manure can contaminate groundwater if the manure is applied in excess of agronomic rates. Clark and others (2006) show that nitrogen source amounts vary throughout the study area with fertilizer and (or) cattle manure accounting for most nitrogen input. The dissolved nitrate from nitrogen input is readily transported to groundwater because of the well-drained soils and highly permeable basalt in the study area. Nitrate persists after it reaches the aquifer because the highly oxic groundwater prevents denitrification. Frans and others (2012) reported that nitrate concentrations in groundwater have increased across much of the study area since 1992.

The groundwater system in the study area consists of two aquifers: a regional basalt aquifer and a local perched aquifer (fig. 1). The regional basalt aquifer underlying the eastern Snake River Plain provides most of the groundwater that moves through the study area. The local perched aquifer (fig. 1) overlying the eastern Snake River Plain regional basalt aquifer in Minidoka and Cassia Counties is a small, localized aquifer that was not included in the subregional model.
The eastern Snake River Plain regional basalt aquifer, which encompasses the study area, primarily comprises vesicular and fractured olivine basalt flows (Quaternary age) of the Snake River Group (Whitehead, 1992). These basalt flows average from 20 to $25 \mathrm{ft}$ thick, but in places can exceed $1,000 \mathrm{ft}$ thick. The top of the basalt generally is less than $100 \mathrm{ft}$ below land surface throughout this part of the plain.

Layered basalt flows in the eastern Snake River Plain aquifer yield exceptionally large volumes of water to wells and springs. Individual well yields are some of the highest in the Nation, typically ranging from 2,000 to $3,000 \mathrm{gal} / \mathrm{min}$ to as much as 7,000 gal/min with minimal drawdown (Whitehead, 1992; Lindholm, 1996). Transmissivity commonly is $100,000 \mathrm{ft}^{2} / \mathrm{d}$ and can be as high as 1,000,000 $\mathrm{ft}^{2} / \mathrm{d}$ (Whitehead, 1992). Locally, aquifer properties can vary greatly; however, on a regional scale the variability is minimal.

Regional groundwater in the eastern Snake River Plain aquifer moves from the northeast to the southwest (Rupert, 1997). Groundwater is discharged as springs and seeps to the Snake River along the reach bordering Twin Falls, Jerome, and Gooding Counties (fig. 1). This reach of the Snake River is known as the Thousand Springs area and is located in the downstream part of the mid-Snake reach that extends from King Hill to Milner Dam. Groundwater discharge to this reach of the Snake River increased considerably from about 1910 through the early 1950s (Kjelstrom, 1992). The increase is attributed to recharge from surface-water irrigation north of the Snake River. Since the early 1950s, groundwater discharge to the Snake River has decreased as a result of (1) increased groundwater withdrawals for irrigation (Moreland and others,

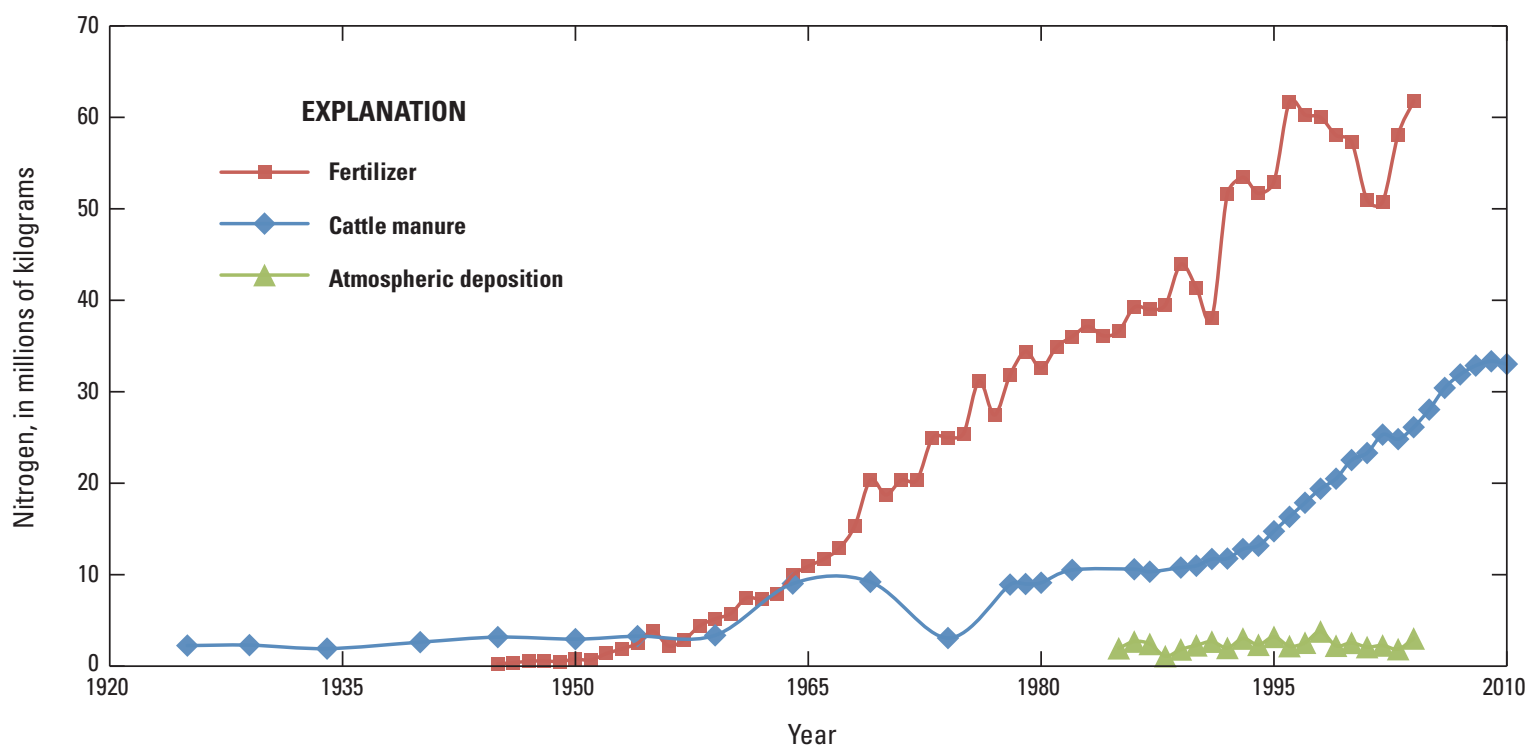

Figure 3. Increased nitrogen input in the past 50 years for fertilizer, and in the past 20 years for dairy and beef cattle, in six mid-Snake counties, south-central Idaho. Data from Ruddy and others (2006) as modified by Gronberg and Spahr (U.S. Geological Survey, written commun., 2008), and U.S. Department of Agriculture (2010). 
1976), (2) introduction of efficient irrigation practices such as conversion from flood to sprinkler irrigation, and (3) local droughts (Kjelstrom, 1992).

In the Burley area (fig. 1), a local perched aquifer is located above a blue-clay layer about 60 to $120 \mathrm{ft}$ below land surface (Rupert, 1997). In this perched aquifer, water moves northward at the southern boundary of the local alluvial aquifer and moves westward near the western boundary. The water level in the perched aquifer is about $100 \mathrm{ft}$ above water levels of the Snake River Plain aquifer. The perched aquifer is recharged predominantly from the infiltration of irrigation water. Several wells completed in this aquifer go dry seasonally after irrigation ceases and become operational again after the start of the next irrigation season (Rupert, 1997).

\section{Previous Investigations and Models}

The water resources of the mid-Snake region have been studied in investigations of regional and local hydrologic systems of Idaho, including investigations of the Snake River Plain in southern Idaho that were part of the USGS Regional Aquifer System Analysis (RASA) and National Water-Quality Assessment (NAWQA) programs. The RASA and NAWQA programs in southern Idaho have produced an assemblage of geologic, hydrologic, and water-quality information about the groundwater systems in the region, as well as computer simulation of those systems. Whitehead (1992) provided an extensive description of the regional hydrogeologic framework, hydrologic properties, and geologic controls on groundwater movement. Kjelstrom (1995) described streamflow gains and losses and compiled regional groundwater budgets. Garabedian (1992) synthesized hydrologic data and constructed a regional groundwater flow model. State agencies and universities also have created numerical groundwater flow models of the eastern Snake River Plain regional basalt aquifer. The Idaho Department of Water Resources and the University of Idaho created the first model of the aquifer. Many revisions to the model have been released (Cosgrove and others, 1999; Idaho Department of Water Resources 2011). These studies provide the regional context for describing flow in the model area.

\section{Eastern Snake River Plain Model}

The first regional, three-dimensional groundwater flow model of the eastern Snake River Plain aquifer system was developed and calibrated during the USGS RASA program (Garabedian, 1992). The goal of the eastern Snake River Plain modeling study was to reproduce known aquifer conditions (for example, head and spring discharge) within reasonable ranges of values, and to examine the hydrologic effects of changes in model input data through sensitivity testing. Initial values of aquifer hydraulic properties, recharge, discharge, and pumpage were estimated for model input based on geologic and hydrologic information. Model output was compared with known aquifer conditions to determine whether the initial estimates were reasonable. The model was tested to determine its sensitivity to changes in transmissivity, storage coefficient, aquifer leakance, recharge, riverbed or spring-outlet conductance, groundwater pumpage, and boundary flux. Input data were adjusted within reasonable ranges to achieve a better fit to known conditions. Adjustments were made to leastknown and to most-sensitive model parameters. Simulation results indicated how the aquifer might have responded to past stresses, such as increased pumping and reduced recharge, and how the aquifer might respond to hypothetical stresses in the future.

The three-dimensional, finite-difference, groundwaterflow model MODFLOW-88 (McDonald and Harbaugh, 1988) was used to develop the eastern Snake River Plain model. Garabedian (1992) subdivided the regional aquifer system vertically into four model layers. Layer 1 represents the upper $200 \mathrm{ft}$ of the aquifer system; layer 2 represents the next $300 \mathrm{ft}$ below. Layers 1 and 2 contain Quaternary basalt of the Snake River Group and Tertiary basalt. Layers 3 and 4 are of lesser areal extent, and are present only where basalt of the Snake River Group and interlayered sedimentary rocks are greater than $500 \mathrm{ft}$ thick. Layer 3 is less than or equal to $500 \mathrm{ft}$ thick, and is present only across the central part of the Snake River Plain. Layer 4 ranges in thickness from 0 to about 3,000 ft in the central part of the plain.

Local aquifers perched above the regional aquifer system were not simulated, although recharge to perched aquifers was assumed to reach the regional aquifer. Vertical hydraulic conductivity was assumed to be anisotropic because of low-hydraulic-conductivity basalt between permeable flow tops and fine-grained layers within sand and gravel zones. Horizontal hydraulic conductivity was assumed to be isotropic because two-dimensional simulations indicated small differences in model simulation results between isotropic and anisotropic conditions (Garabedian, 1992).

A steady-state model was constructed using 1980 wateryear fluxes (Garabedian, 1992, table 16). The 1980 fluxes were assumed to approximate the average annual flux for 1950-80. During that period, hydrologic conditions were stable relative to conditions from 1880 to 1950. Groundwater recharge was assumed to equal discharge (steady-state conditions) from 1950 to 1980 because irrigation diversions and groundwater levels were assumed to be stable relative to conditions from 1880 to 1950 (Garabedian, 1992, fig. 8 and pl. 4). Declines in groundwater levels due to pumping, climatic variations, and decreased surface-water diversions from 1950 to 1980 generally were small, and changes in storage accordingly were small (about 1 percent). These small changes in storage were included as part of the recharge period by including them in the computation of approximate steady-state fluxes. Recharge from irrigation was assumed to take place directly below surface-water-irrigated areas. 


\section{Advective Transport Modeling}

Quantitative estimates of groundwater flow directions and travel times for advective flow in the eastern Snake River Plain model were made by Ackerman (1995) using the MODPATH advective transport particle-tracking package (Pollock, 1989). The advective transport model required additional and updated information about the nature of flow across model boundaries, aquifer thickness, and porosity. Values of porosity used in calibration were constrained by prior information about basalt porosity reported for more than 1,500 individual cores from test holes, wells, and outcrops near the south side of the Idaho National Engineering Laboratory (Knutson and others, 1990, 1992) occupying roughly the northwest one-third of the eastern Snake River Plain model area. Other estimates of porosity were derived from other transport models, materials balances, and general aquifer descriptions. Porosity values were determined for large core samples using volumetric and gravimetric methods and a helium porosimeter. Porosities were $0.08-0.25$ in the central 80 percent of samples, and porosities were $0.11-0.21$ in the central 50 percent of samples. Previous models used porosity estimates of 0.10 , materials balances had a porosity range of 0.06 to 0.10 , and general aquifer descriptions used porosity estimates of $0.05-0.15$.

Two radiologic contaminants, iodine 129 and tritium (hydrogen-3), are relatively conservative tracers that were used to determine the optimum porosity value (Ackerman, 1995). The contaminants were introduced directly through a 590-ft-deep injection well at the Idaho Chemical Processing Plant at the Idaho National Engineering Laboratory starting in 1953 (Mann and Cecil, 1990, p. 13). Tritium was first detected in wells near the south boundary of the Idaho National Engineering Laboratory 30 years later (Mann and Cecil, 1990, p. 27), and iodine-129 was detected approximately 38 years later (Ackerman, 1995). The half-life of iodine-129 is 15.7 million years and that of tritium is 12.4 years. The porosity was adjusted until simulated travel times matched measured travel times. The calibration value for porosity was 0.21 for iodine-129 and 0.25 for tritium, which corresponds with the higher porosity values measured in the core samples. The travel time for iodine-129 was considered more useful for comparison with predicted travel times because of a lower analytical detection limit, longer half-life, and longer flow path. The resulting value for porosity was 0.21 .

\section{Subregional Model Development}

Clark and others (2006) converted the eastern Snake River Plain model from MODFLOW-88 to MODFLOW-2000 (Harbaugh and others, 2000), and rediscretized the model grid from the original 4-mi grid cells to approximately 1-mi grid cells. Clark and others (2006) derived flow boundary conditions and initial estimates of aquifer properties from the calibrated eastern Snake River Plain model. Clark and others (2006) "clipped" the eastern Snake River Plain model at column 25, near the eastern boundary of Minidoka County (fig. 4), to include only the western part of the model. Flow values across column 25 of the model were input as constant flow into the subregional model cells in each model layer along the upgradient boundary using the well package. The model was run with this new configuration; model simulated results of water levels and budget values were checked qualitatively against the original model. Comparison results were nearly identical to the original model.

No changes were made to the model configuration that affected groundwater elevations, discharge from springs, recharge sources, and other critical values or conditions. Boundary conditions also were the same, simulated as specified flux and head-dependent flux using the recharge, well, and river packages except, as noted above, along the eastern boundary of the model at column 25. Additionally, Clark and others (2006) did not change the hydraulic parameters from the original eastern Snake River Plain model. The only change to the subregional flow model resulted from the use of a smaller grid cell size than the one used in the eastern Snake River Plain model. The eastern Snake River Plain model incorporated the use of wells as recharge sources. Because of the smaller grid size used in the subregional model, Clark and others (2006) increased the number of cells to which recharge was input to incorporate more accurately the recharge volume; otherwise, the model would not match the original results. Therefore, the total volume of recharge remained the same as in the eastern Snake River Plain model, but this volume was distributed over 16 times the number of recharge wells. Wherever possible, Clark and others placed these additional recharge wells in the rediscretized adjacent grid cell blocks. The volume of each original recharge well was evenly distributed between the 16 smaller cells. A few minor adjustments in the locations of these new recharge wells were needed so the new simulations matched the original simulations, especially along the model boundary.

\section{Solute Transport Modeling}

The transport of dissolved nitrate in the mid-Snake region groundwater system was simulated by Clark and others (2006) by using the USGS three-dimensional solute-transport model MOC3D (Konikow and others, 1996; Kipp and others, 1998), which was developed for use with MODFLOW 2000. MOC3D simulates three-dimensional solute transport in flowing groundwater, computing changes in concentrations of a dissolved constituent over time that can be caused by factors such as advective transport, hydrodynamic dispersion, and mixing or dilution. MOC3D uses the method of characteristics to solve the transport equation for a given time step based on groundwater flow rates computed with MODFLOW (Konikow and others, 1996; Kipp and others, 1998). 


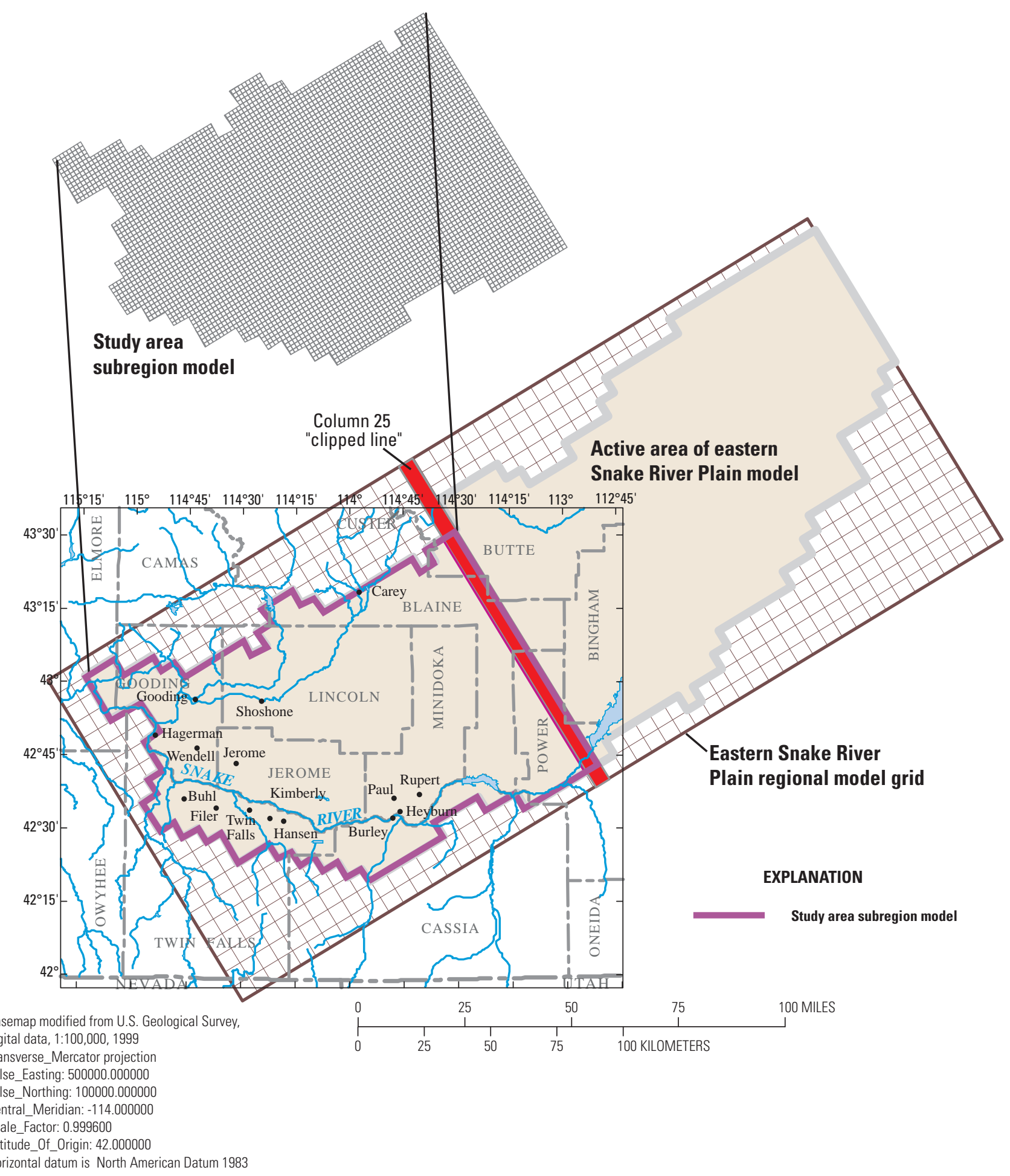

Figure 4. Extent of a subregional groundwater flow model of the mid-Snake region within the eastern Snake River Plain regional model, south-central Idaho (from Clark and others, 2006). 
The conceptual model of nitrogen input developed by Skinner and Donato (2003) was used in the subregional model as a Geographic Information System (GIS) nitrogeninput layer. Skinner and Donato estimated nitrogen input and losses using county-level estimates of nitrogen input from five sources including cattle manure and fertilizer, and improved on the county-level estimates by applying the nitrogen input only to land-use categories related to that particular type of nitrogen input. For example, nitrogen input from fertilizer was applied only to agricultural and residential lands. Rangeland received nitrogen input only from precipitation. Input from the nitrogen layer was incorporated in the subregional model by using the area wells function in all active model cells in layer 1 . The area wells function allows for the nitrogen input layer to be introduced in the subregional model by assigning a volumetric stress to each cell. The stress applied is a small volume of water that contains a specified concentration of nitrogen derived from the source layer. The initial preagriculture background concentration applied throughout the model was $0.5 \mathrm{mg} / \mathrm{L}$ in the upper model layer, $0.4 \mathrm{mg} / \mathrm{L}$ in the second and third underlying layers, and $0.3 \mathrm{mg} / \mathrm{L}$ in the fourth underlying layer.

Calibration of the transport results by Clark and others (2006) was accomplished by comparing nitrate concentrations from the simulations with nitrate concentration data from about 300 wells throughout the study area, and temporal nitrate concentrations from 11 springs that discharge into the Snake River. The calibration involved adjusting a multiplication factor applied to a nitrogen source layer to best represent nitrate conditions in groundwater. Rigorous calibration techniques, such as parameter estimation, were not used in the calibration process. Calibration was done mostly using trial and error techniques.

\section{Methods of Investigation}

Groundwater nitrate concentration data were compiled from several sources and imported into a GIS data layer. GIS data on depth to groundwater, groundwater velocity, total nitrogen input from cattle manure, total nitrogen input from fertilizer, percent land use, hydrogeology, precipitation, and soils were compiled to provide input data to groundwater nitrate probability models. Upgradient 90-degree, wedgeshaped zones of influence were calculated for each well where groundwater-quality data were available to determine either the total or average of the probability model input data upgradient from each sampled well. The optimum size for each 90-degree, wedge-shaped zone was calculated using groundwater age and groundwater-flow velocity. Two nitrogen input layers were evaluated for this report to determine which input layer is most effective in simulating measured nitrate concentrations in groundwater. The first nitrogen input layer is the one used by Skinner and Donato (2003), referred to hereafter as "SD." The second nitrogen input layer is the same as used for SD, but was modified using a map of the probability of elevated nitrate concentrations to prorate nitrogen input to groundwater. The second nitrogen input layer is referred to hereafter as "SDPROB." Each nitrogen input layer (SD and SDPROB) was used in separate solute transport simulations, and the results were compared to determine which layer was best reproduced measured nitrate concentrations. In each transport simulation model, the parameter estimation software UCODE_2005 (Poeter and others, 2005; Hill and Tiedeman, 2007) was used to estimate the multiplication factor for the nitrogen input layers that accounts for the conversion of nitrogen to nitrate in soils and the transport of nitrate through the unsaturated zone to the aquifer. The UCODE_2005 software also was used to compare the effectiveness of the two alternative nitrogen input layers, as compared to measured nitrate concentrations.

\section{Hydrogeologic and Anthropogenic Data}

\section{Groundwater-Quality Data}

Groundwater-quality data on nitrate concentrations in samples collected from water in wells and springs for 2003 through 2007 were compiled from several sources: the Idaho State Department of Agriculture (Tonia Mitchell, Idaho Department of Environmental Quality, unpub. data, 2008), the Idaho Division of Environmental Quality (Joe Baldwin and Tonia Mitchell, Idaho Department of Environmental Quality, unpub. data, 2008), the Bureau of Reclamation (Bill Stroud, Bureau of Reclamation, unpub. data, 2008), the U.S. Environmental Protection Agency (2008), and the U.S. Geological Survey (2008) (fig. 5). The nitrate data were filtered for data collected only in July during 2003-07, resulting in 525 separate nitrate concentration values from wells and springs. The nitrate data were filtered further for only the most recent data for a well or spring. All nitrate data were from water samples collected in wells completed at approximately the same depth and in the same hydrogeologic unit, the Snake River Group basalts. 


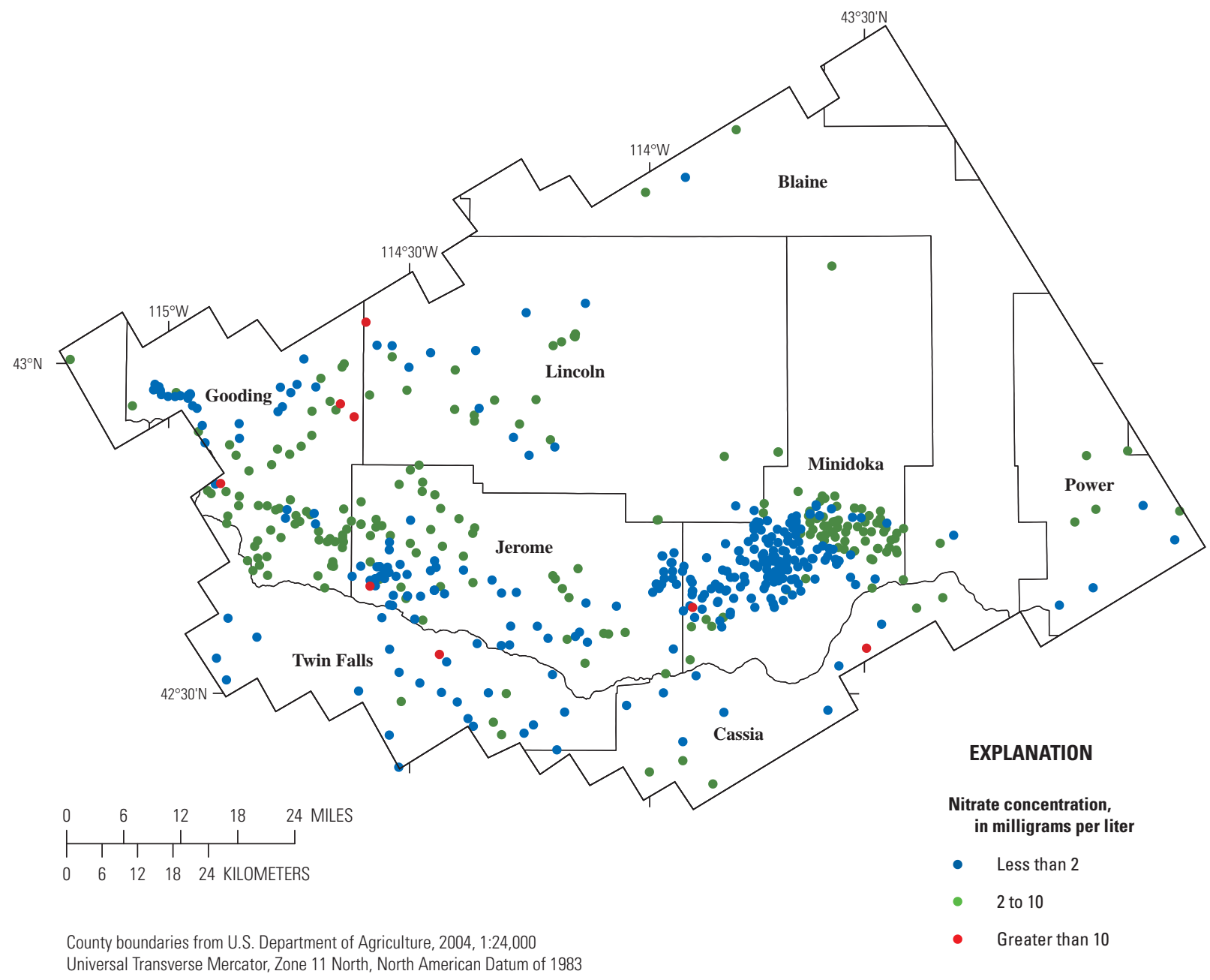

Figure 5. Nitrate concentration data from groundwater used to create probability maps and to calibrate nitrogen input to the subregional model in the mid-Snake region, south-central Idaho.

\section{Geographic Information System Data}

GIS data on cultural, hydrologic, land use, soils, and precipitation factors were compiled to input to the groundwater-nitrate-probability models. The GIS data consisted of depth to groundwater, groundwater velocity, total nitrogen input from cattle manure, total nitrogen input from fertilizer, percentages of land use, precipitation, and soils (table 1).
Two sets of land-use data were evaluated: (1) a landuse dataset developed by the Bureau of Reclamation (Reclamation) (Bureau of Reclamation, unpub. data, 1987, 1992), and (2) the 2001 National Land Cover Database (NLCD) from the USGS (LaMotte, 2008). The Reclamation and NLCD data were evaluated independently of each other during construction of the probability models to determine which land-use data produced the best correlation with elevated nitrate concentrations. 
Table 1. Independent variables used to estimate probability of nitrate concentrations greater than 2 milligrams per liter in groundwater, mid-Snake region, south-central Idaho.

[Independent variable: Reclamation, land cover developed by the Bureau of Reclamation; Daymet, a model that generates daily surfaces of temperature, precipitation, humidity, and radiation over large regions of complex terrain; NLCD, National Land Cover Database; PRISM, Parameter-elevation Regressions on Independent Slopes Model. A bbreviations: ft, foot; in., inch; lbs/acre, pounds per acre; mm, millimeter; mm/yr, millimeter per year; m/d, meter per day; $>$, greater than]

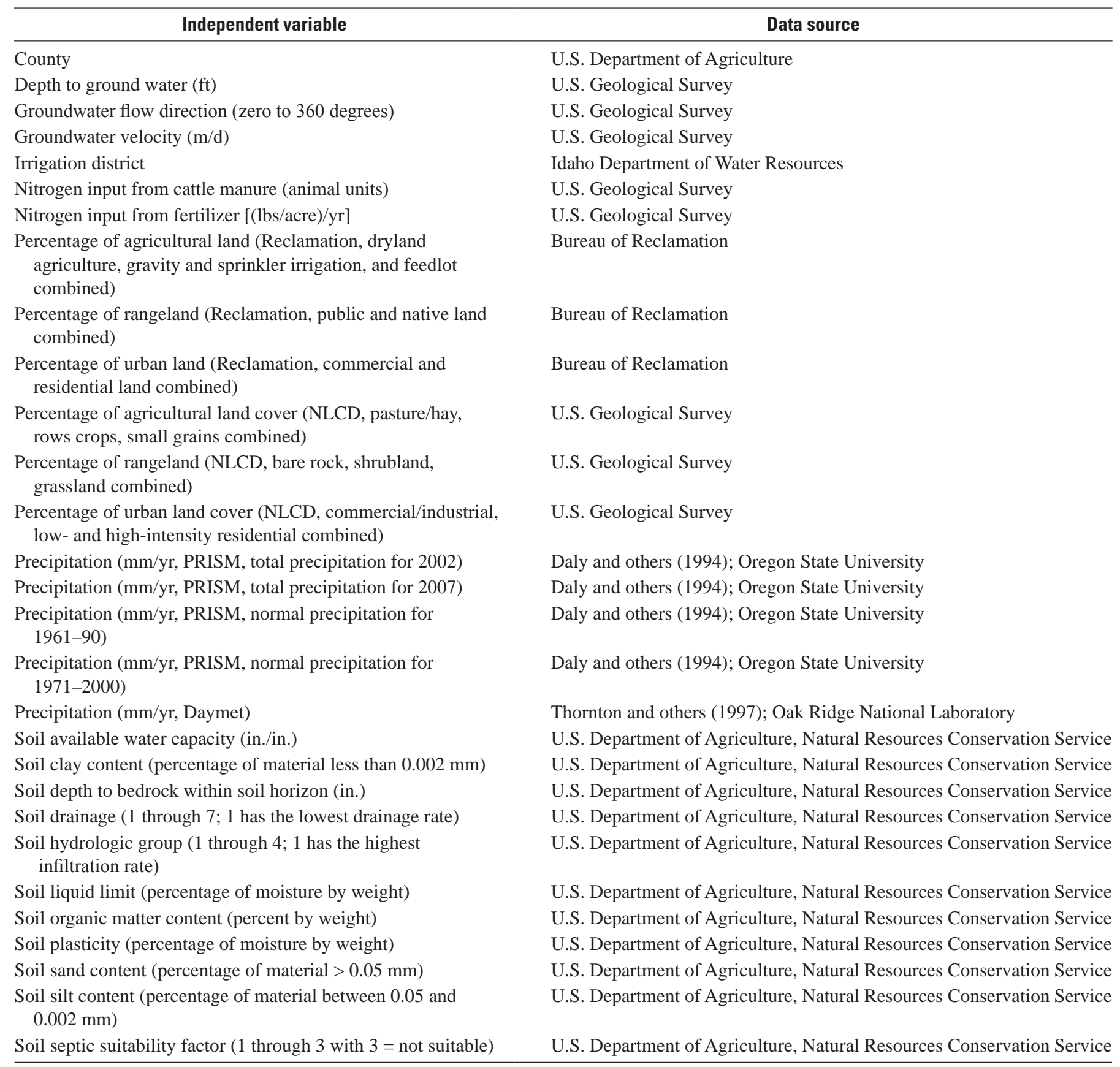


The Reclamation land-use dataset contains several categories, including dry farm agriculture, gravity irrigation, sprinkler irrigation, feedlot, public land, native land, commercial land, and residential land. Similar Reclamation land use categories were combined to make Reclamation and NLCD data comparable and to ease development of the probability models. An agricultural land category was created by combining the dry farm, gravity irrigation, sprinkler irrigation, dairy, and feedlot categories. A rangeland category was created by combining the public land and native land categories. An urban land category was created by combining the commercial land and residential land categories.

The NLCD land-use data contain several categories, including pasture/hay, row crops, small grains, bare rock, shrubland, grassland, commercial/industrial, low-intensity residential, and high-intensity residential. NLCD land use categories also were combined. An agricultural land category was created by combining the pasture/hay, row crops, and small grains categories. A rangeland category was created by combining the bare rock, shrubland, and grassland categories. An urban category was created by combining the commercial/ industrial, low-intensity residential, and high-intensity residential categories.

Precipitation data sets were derived from two sources. One precipitation data set was developed by Daly and others (1994) using the Parameter-elevation Regressions on Independent Slopes Model (PRISM). PRISM uses climatic point data and a digital elevation model to generate gridded estimates of climatic parameters. PRISM has been used extensively to map precipitation and minimum and maximum temperatures throughout the United States, Canada, and other countries. For this study, four PRISM data sets were considered: the total annual precipitation for 2002 and 2007, and the normal precipitation for 1961-90 and 1971-2000. The other precipitation data set, Daymet, was developed by Thornton and others (1997) from daily observations from approximately 6,000 stations in the U.S. National Weather Service Co-op network and the Natural Resources Conservation Service SNOTEL network. The interpolated daily meteorological observations were summarized to represent the period of record, 1980-97.

Soils data were obtained from the Soil Survey Geographic database (SSURGO), which was developed by the Natural Resources Conservation Service at approximately 1:24,000 scale (U.S. Department of Agriculture, 2008). The SSURGO soils data include information on soil available water capacity, soil clay content, depth to bedrock within the soil horizon, soil drainage, soil hydrologic group, soil liquid limit, soil organic matter content, soil plasticity, soil sand content, and soil silt content. The SSURGO data include a soil factor called "the soil septic suitability factor," which rates the suitability of a certain soil for use by septic-tank absorption fields. The suitability factor is based on soil ratings of saturated hydraulic conductivity, depth to water table in the soil layer, ponding, depth to bedrock in the soil layer, and flooding between soil depths of 24-72 in. Some SSURGO soil variables, such as soil hydrologic group and soil drainage, are categorical variables. To facilitate modeling with logistic regression, categorical variables were converted to numerical variables (table 1). For instance, soil drainage has seven categories: very poorly drained, poorly drained, somewhat poorly drained, moderately well-drained, well-drained, somewhat excessively drained, and excessively drained. Soil drainage was converted to a numerical rating of 1 for very poorly drained soil to 7 for excessively drained soil.

The depth-to-groundwater map was produced using a GIS. Depth-to-groundwater data were obtained from the USGS National Water Information System database, where groundwater level or depths-to-groundwater data for 436 wells were retrieved (U.S. Geological Survey, 2008). The data were filtered for water levels measured during May to September 2001-04. Only the earliest groundwater-level measurement was used from wells containing multiple water-level data. The depth-to-groundwater map was created using a spline interpolator technique (Environmental Systems Research Institute, Inc., 2011) that includes barriers to incorporate the effects of linear features on groundwater levels, such as aquifer boundaries and rivers. The spline interpolator is a deterministic interpolator that creates a smooth surface that must pass through each measured value. It is ideal for smoothly varying surfaces such as a potentiometric surface. The output of the spline interpolator is a grid with an interpolated value at each cell except for cells that contain an actual groundwater-level measurement, which are assigned the measured groundwater level. Groundwater-flow system boundaries and the Snake River were incorporated as barriers to the interpolator.

The 1:24,000-scale county boundaries of Idaho are from the U.S. Department of Agriculture (2003), and the irrigation district dataset is from the Idaho Department of Water Resources (2009). The county boundary and irrigation district data sets were clipped to the model area. County boundaries and irrigation districts were evaluated as discrete rank variables for the probability models.

Groundwater velocity and flow-direction data were obtained from the subregional model of the eastern Snake River Plain regional aquifer system (Clark and others, 2006). 
The nitrogen input from fertilizer data (October 21, 2008) used for this report were developed by Ruddy and others (2006); the farm and nonfarm estimates by Ruddy and others (2006) were modified by Gronberg and Spahr (U.S. Geological Survey, written commun., 2008). Although the 2002 nitrogen input fertilizer data are estimated for each county, each county in the study area contains a significant fraction of rangeland. Fertilizers would not likely be applied to rangeland so a GIS was used to apply the nitrogen input to land-use types typical of fertilizer use, (for example, agricultural and residential land). Because it was not known whether the Reclamation or the NLCD data were more accurate, both datasets were used to assign fertilizer use separately. During logistic regression modeling, nitrogen input was simulated using both land-use data sets and the most significant data set was used in the final probability models and maps.

A dairy GIS dataset was created for this report by hand digitizing dairy polygons from digital aerial photography (U.S. Department of Agriculture, 2004). These digitized polygons were compared with point locations of dairies and feedlots obtained from the Idaho State Department of Agriculture (written commun., 2004) to verify the digitized polygons were accurately identified. The numbers of dairy cattle located at each polygon were estimated using 2002 data from the U.S. Department of Agriculture National Agricultural Statistics Service (U.S. Department of Agriculture, 2010).

\section{Delineating Areas Contributing to Wells}

Previous statistically based groundwater probability assessments have delineated the land cover and hydrogeologic factors potentially affecting groundwater quality by using circular buffers of various radii (Rupert, 2003). These buffers represent a percentage of total area, an average, or the sum of the factors affecting groundwater quality. A 1,640-ft (500 $\mathrm{m}$ ) radius has been the most common radial length for the circular buffer method (Eckhardt and Stackelberg, 1995; Nolan and others, 2002). If the groundwater flow direction is not known, circular buffers provide a first approximation of the contributing area. However, if groundwater flow directions are known, an upgradient, wedge-shaped buffer might provide a more accurate delineation of the contributing area (fig. 6). Lorenz and others (2003), Gurdak and Qi (2006), Gurdak and others (2007), and Gurdak (2008), characterized land use near individual wells within an upgradient, wedge-shaped sector and determined that the sector method presented a more accurate estimate of land use affecting water quality in an individual well than the circular-buffer method.

The sector method to delineate the contributing area of recharge to wells was used for this report using information from the subregional model along with groundwater ages to determine the size and orientation of the sector. The flow direction at each well was derived from the upper layer of the subregional model. The radial length of each sector was determined based on groundwater age and groundwater flow velocity. Groundwater ages were determined by Plummer and others (2000), who used chlorofluorocarbons, and tritium and helium-3 to determine apparent groundwater recharge dates in the study area. Plummer and others (2000) subdivided the groundwater quality into two groups, one located beneath agricultural areas and affected by anthropogenic activities, and the other located beneath rangeland areas (upgradient of the agricultural areas) that have not been affected by anthropogenic activities. The median age of groundwater beneath the agricultural areas is about 5 years. The median groundwater flow velocity calculated by the flow model is $12 \mathrm{ft} / \mathrm{d}$. After groundwater velocity was multiplied by groundwater age, 21,982 ft (6,700 m) was determined to be a reasonable radius for the pie-shaped areas of influence. A radial sector length of 21,982 ft (6,700 m) was used to determine average depth to groundwater, groundwater velocity, nitrogen input from fertilizer and manure, percentage of land cover, and soil properties within each wedge-shaped area, and then was used in the logistic regression modeling.

\section{Logistic Regression Statistical Method}

Logistic regression (Hosmer and Lemeshow, 1989; Helsel and Hirsch, 1992; Kleinbaum, 1994) is a statistical method that predicts the probability of the occurrence of the target water-quality constituent to be greater than a certain level or threshold. For instance, for this report, logistic regression was used to predict the probability of detecting nitrate concentrations in groundwater greater than or equal to $2 \mathrm{mg} / \mathrm{L}$. Logistic regression is similar conceptually to multiplelinear regression because relations between one dependent variable and several independent variables are evaluated. Whereas multiple-linear regression returns a continuous value for the dependent variable, logistic regression returns the probability of a positive binomial outcome (in this case, nitrate concentrations were or were not greater than $2 \mathrm{mg} / \mathrm{L}$ ) in the form:

$$
P=\frac{e^{x}}{1+e^{x}}
$$

where

$\mathrm{P}$ is the probability of nitrate concentrations being greater than $2 \mathrm{mg} / \mathrm{L}$,

$x$ is $\beta_{0}+\beta_{1} x_{1}+\beta_{2} x_{2}+\ldots .+\beta_{i} x_{i}$,

$\beta_{\mathrm{i}}$ is logistic regression coefficient,

$x_{i}$ is value for the independent variables such as soil drainage or depth to groundwater, and

$i$ is the number of variables. 


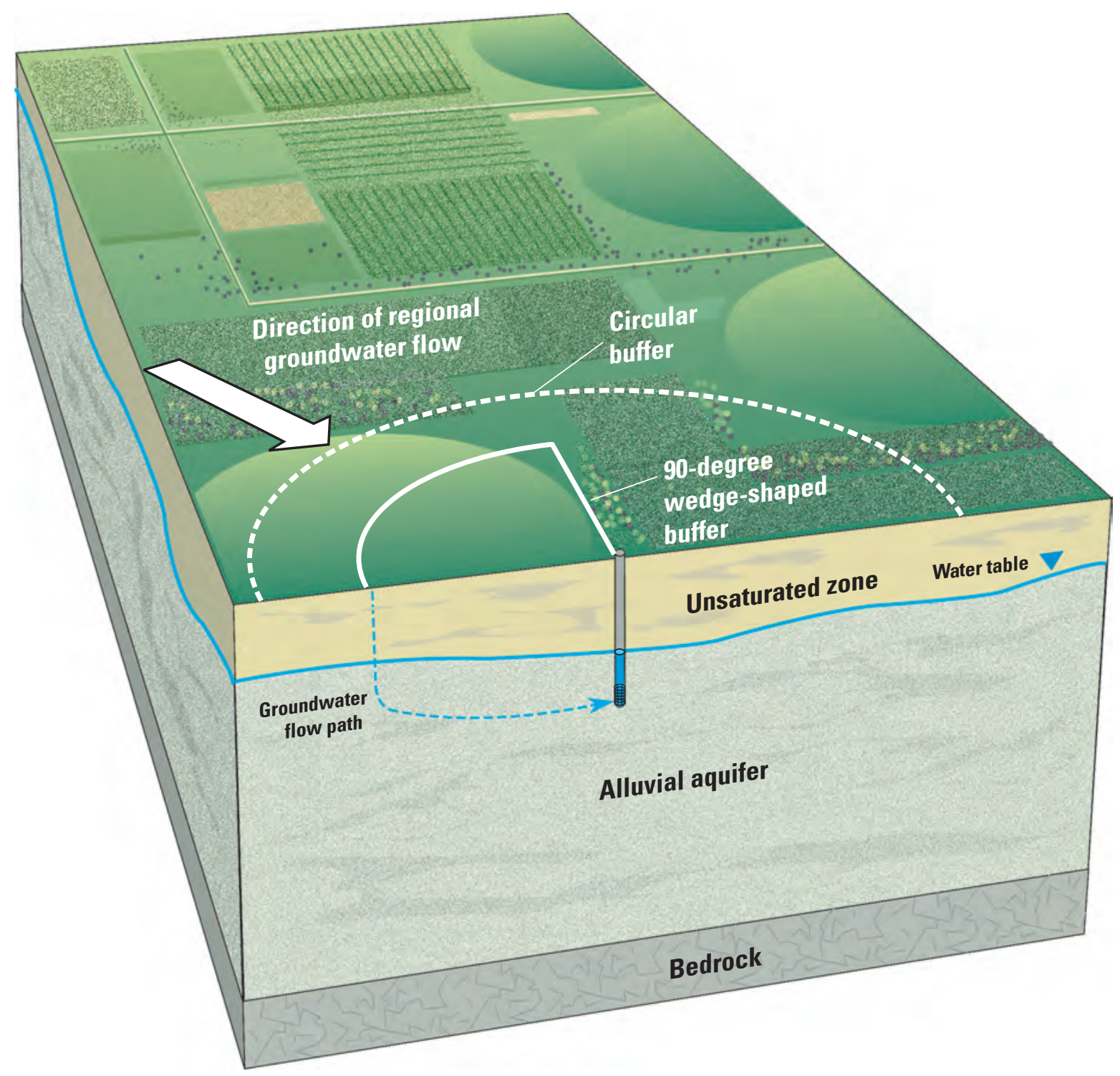

Figure 6. Conceptual diagram of wedge-shaped 90-degree buffer and circular buffer used to delineate areas that contribute recharge to a well (from Gurdak and Qi, 2006).

Logistic regression calculates several statistical parameters that determine the predictive success of the model. The log-likelihood ratio measures the success of the model as a whole by comparing measured values with predicted values (Hosmer and Lemeshow, 1989, p. 13); specifically, the ratio tests whether model coefficients of the entire model are significantly different from zero. The most significant model is the one with the highest log-likelihood ratio, taking into account the number of independent variables (degrees of freedom) used in the model. The log-likelihood ratio follows a chi-squared distribution, and the computed p-value indicates whether model coefficients are significantly different from zero. Therefore, the computed $\mathrm{p}$-value is the significance level attained by the data; the smallest p-value indicates the best model. A p-value of 0.05 indicates a probability of a correct decision (regarding null hypothesis rejection) of 0.95 ; a p-value of 0.01 indicates a probability of 0.99 . 
McFadden's rho-squared (SYSTAT Software, Inc., 2004) is a transformation of the log-likelihood statistic and is intended to mimic the $r$-squared of linear regression. Rho-squared is always between zero and 1; a rho-squared approaching 1 corresponds to results that are more significant. Rho-squared tends to be smaller than r-squared, so a small number does not necessarily imply a poor fit. P-values calculated for each independent variable indicate the statistical significance that each variable has on the overall logistic regression model. Independent variables were excluded from the models if their individual p-values were greater than 0.1 . The sensitivity is calculated as the number of correctly predicted events (nitrate detections greater than $2 \mathrm{mg} / \mathrm{L}$ ) divided by the total number of observed events (SYSTAT Software, Inc., 2004). The specificity is calculated as the number of correctly predicted reference events (no nitrate detections greater than $2 \mathrm{mg} / \mathrm{L}$ ) divided by the total number of observed reference events. The total correct predictions is calculated as the number of correctly predicted events plus the number of correctly predicted reference events divided by the total number of all events. To verify the models, the percentage of actual detections was plotted with the predicted probability of detections by using deciles of risk, in which observations are partitioned into 10 groups (SYSTAT Software, Inc., 2004, p. II-238).

The logistic regression model was built by including each individual variable in the model, evaluating the resulting test statistics, and deciding whether to include or reject the variable. Model validity and accuracy were determined by evaluating the log-likelihood ratio, McFadden's rho-squared, the model sensitivity and specificity, and the p-values calculated for each independent variable. During construction of the logistic regression model, the data were checked for multicolinearity by calculating the variance inflation factor. Multicolinearity means that at least one independent variable is closely related to one or more other independent variables. All variance inflation factors in the final models were less than 10, which is the level of concern indicated by Helsel and Hirsch (1992, p. 306).

\section{Construction of Probability Maps}

A map showing the probability of elevated concentrations of nitrate in groundwater was developed using the logistic regression methods. Before constructing the map, the GIS data were converted to grids with a 295 -ft (90 m) cell size. The GIS independent variables then were converted to an average, a sum, or percentage of composition of the area upgradient within a wedge-shaped buffer with a 21,982-ft (6,700-m) radius, depending on the independent variable. The logistic regression model, similar to equation 1 , was entered into a GIS, and a probability rating was calculated for each grid cell in the study area.

\section{Groundwater Probability Modeling}

Logistic regression statistical modeling techniques were used to develop the statistical model that estimates the probability of nitrate concentrations in groundwater greater than $2 \mathrm{mg} / \mathrm{L}$. A concentration of $2 \mathrm{mg} / \mathrm{L}$ was selected because it is close to the median concentration of all nitrate samples used to build the logistic regression models. Using a nitrate concentration close to the median concentration helps to develop the most robust statistical model (Rupert, 2003).

Depth to groundwater, precipitation, soil available water capacity, soil depth to bedrock within soil horizon, and soil liquid limit were significant variables in the model (table 2). Individual p-values for each of these variables were less than 0.05 , indicating that they are significantly correlated with elevated concentrations of nitrate in groundwater (table 2). Many of the same variables are significant variables in nitrate probability maps in other areas of the Nation (Rupert, 2003; Rupert and Plummer, 2009). The rho-squared value for the final probability model was 0.158 . The total correct predictions of the model is 0.616 with a sensitivity of 0.677 and a specificity of 0.527 .

\section{Probability Model Verification}

To verify the model, the percentage of actual detections was plotted with the predicted probability of detections using deciles of risk (fig. 7). An r-squared value of the plot of actual detections with the predicted probability of detections was 0.998 , verifying it was a highly effective model.

Table 2. Logistic regression model simulation, coefficients, and individual $p$-values of independent variables significantly related with the probability of detecting measured nitrate concentrations greater than 2 milligrams per liter in groundwater of the MidSnake Region, south-central Idaho.

[Independent variables: Daymet, a model that generates daily surfaces of temperature, precipitation, humidity, and radiation over large regions of complex terrain. Probability of nitrate greater than $\mathbf{2} \mathbf{~ m g / L}$ : Values not enclosed in parentheses are logistic regression coefficients; values enclosed in parentheses are individual p-values. A bbreviations: ft, foot; in., inch; in./in., inch per inch; mg/L, milligram per liter; mm/yr, millimeter per year]

\begin{tabular}{lc}
\hline \multicolumn{1}{c}{ Independent variables } & $\begin{array}{c}\text { Probability of nitrate } \\
\text { greater than } \mathbf{2 ~} \mathbf{~ m g} / \mathbf{L}\end{array}$ \\
\hline Depth to groundwater (ft) & $-8.864(0.000)$ \\
Precipitation (mm/yr, Daymet) & $0.463(0.012)$ \\
Soil available water capacity (in./in.) & $0.028(0.000)$ \\
Soil depth to bedrock within soil & $0.014(0.000)$ \\
$\quad$ horizon (in.) & \\
Soil liquid limit (percentage of moisture & $0.058(0.034)$ \\
by weight) & \\
\hline
\end{tabular}




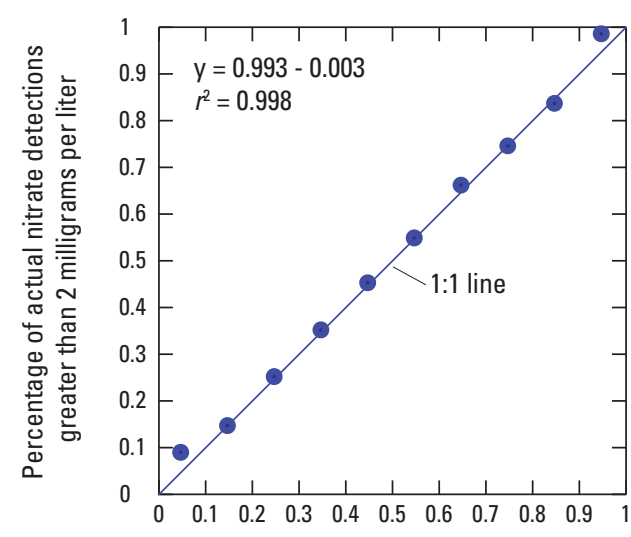

Predicted probability of detecting nitrate concentrations greater than 2 milligrams per liter

Figure 7. Deciles of risk plot showing the high correlation between percentage of actual nitrate detections and predicted probability of detecting nitrate concentrations groundwater, using 10 equal intervals.

\section{Estimating Nitrogen Input to the Subregional Model}

The SD and SDPROB nitrogen input layers were evaluated using the subregional model of Clark and others (2006). Both nitrogen input layers used the same 2002 estimates of county-level fertilizer and cattle manure, which allowed the two methods to be directly compared. The primary differences between the two methods are that SD uses the 2002 county-level nitrogen input to agricultural and residential land-use types defined by the Reclamation land-use data set, whereas SDPROB prorates the same nitrogen input based on the logistic regression model.

\section{Nitrogen Input by Skinner and Donato (2003)}

Clark and others (2006) used the SD nitrogen input layer as the basis for the nitrogen source term in the subregional model. They applied a multiplication factor uniformly to SD to adjust the nitrogen input to correlate with measured nitrate concentrations in groundwater. The multiplication factor accounts for the conversion of nitrogen to nitrate in soils and the transport through the unsaturated zone to the aquifer. No rigorous calibration techniques, such as parameter estimation, were used to determine the multiplication factor; calibration was done using trial-and-error techniques. In this study, the multiplication factor was estimated using UCODE_2005. Groundwater-quality data collected during 2003-07 were used in the parameter estimation.

\section{Nitrogen Input Prorated Using a Nitrate Probability Map}

The SDPROB nitrogen input layer was created by multiplying SD cell values by the corresponding value on the nitrate probability map. The probability map ratings range from close to zero (very low probability of nitrate greater than $2 \mathrm{mg} / \mathrm{L}$ in groundwater) to close to one (very high probability of nitrate greater than $2 \mathrm{mg} / \mathrm{L}$ in groundwater). When SD is multiplied by the probability, areas with low probability ratings have a reduced nitrogen input, and areas with high probability ratings maintain the nitrogen input level corresponding to the SD layer. Therefore, the probability map reduces the nitrogen input in areas with a low probability of detecting nitrate concentrations greater than $2 \mathrm{mg} / \mathrm{L}$, but does not increase the nitrogen input in areas with a high probability of detection. The probability map ratings are based on correlations with physical factors, so SDPROB incorporates a more realistic estimate than SD of nitrogen flux to the water table. An optimal multiplication factor for SDPROB also was estimated using UCODE_2005.

\section{Nitrogen Input Optimization and Comparison Using UCODE_2005}

The two nitrogen input layers were compared using the methods of Hill and Tiedeman (2007) and the software UCODE_2005 (Poeter and others, 2005) to determine which layer produces simulated nitrate concentrations from the subregional model that best match measured nitrate concentrations. These comparisons were based on overall model-fit statistics and measured, simulated, and residual point statistics determined at measured nitrate concentration locations.

In this study, UCODE_2005 was used to estimate the optimal multiplication factor for the SD and SDPROB nitrogen input layers by minimizing the sum of squared differences between simulated nitrate concentrations in layer one of the models and corresponding measured nitrate concentrations. The UCODE_2005 calibration data used the 525 nitrate concentration values collected from wells and springs (see section "Groundwater-Quality Data"). The 525 nitrate concentration values represented 320 individual calibration model cells because some model cells contained more than one nitrate concentration sample. In instances where a model cell contained more than one nitrate concentration sample, the mean of the nitrate concentrations was used for calibration of that cell. UCODE_2005 calculates overall model-fit statistics that can be used to evaluate individual model performance. These model-fit statistics were used to determine which nitrogen input layer, SD or SDPROB, had the 
best fit. The model with the best fit was then selected for use in further analysis. It was beyond the scope of this report to evaluate the flow or transport performance of the model; only nitrogen input to the model and the resulting simulated nitrate concentrations were evaluated.

UCODE_2005 model files were created according to the methods described in Poeter and others, (2005), and Hill and Tiedeman (2007). Because the same single parameter (nitrogen input multiplication factor) was estimated in each model, comparison was relatively straightforward using model-fit statistics. UCODE_2005 requires weighting observation data, which also was simplified because only one type of observation data (nitrate concentration) was used, and all weights were set to 1.0 (Hill and Tiedeman 2007, p. 294). After the UCODE_2005 models were established with SD and SDPROB, model-fit-independent statistics were analyzed to identify the effect that measured nitrate concentrations had on the parameter estimation. These statistics identified two observations that had an unusually high effect on parameter estimation. Upon further review, these two observations were determined to represent individual point sources of nitrate that were surrounded by lower areal nitrate concentrations. These observations were omitted from subsequent model runs because they were outliers. Because the model is not capable of single-cell precision (see section, “Model Limitations”), these outliers weaken model performance.

All UCODE_2005 model runs used three different starting values to determine the optimal multiplication factor of either SD or SDPROB: (1) a low-end value of 1, (2) an estimated value of 225 (the multiplication factor used in the Clark and others [2006]), and (3) a high-end value of 10,000 . Using different starting values establishes model uniqueness. Each UCODE_2005 model calculated the same resulting parameter value (232 for SD, and 392 for SDPROB), regardless of the starting value, indicating that a unique solution for the nitrogen input layer multiplication factor is being calculated.

Model linearity, which can affect parameter confidence intervals, was estimated using the Beale's measure that indicates a linear model for values less than 0.26. All models had a Beale's measure four orders of magnitude less than the cutoff value indicating that all the models are linear.

The overall model-fit statistics measure how well a model re-creates the measured observations. The overall model-fit statistics (table 3) indicate that SDPROB more accurately represents nitrogen input than SD; hence, SDPROB re-creates a better match than SD with the measured nitrate observations. The composite scaled sensitivity (CSS) is used comparatively between models; larger CSS values indicate that the observations provide a better estimated model parameter. In this case, SDPROB (CSS=1.97) provides more information in estimating the model parameter than SD (CSS=1.90).
The calculated error variance (CEV) and the standard error (SE) are indicators of the overall magnitude of residuals (measured nitrate concentration minus the simulated nitrate concentration), with the SE as the square root of the CEV. As with the overall model fit statistics, smaller values of the CEV and SE indicate a closer fit between simulated values and the observations. The smaller CEV and SE values for SDPROB indicate that SDPROB better estimates the measured nitrate concentrations than does SD (table 3 ). However, because the $\mathrm{CEV}$ and $\mathrm{SE}$ values for each model occur within the confidence interval of the other model, there is little statistical difference between the two nitrogen input models.

Residual analysis indicates less bias in the SDPROB model than in the SD model. Ideally, plots of simulated nitrate concentrations show a random scatter about the zero residual value. Any variation from this pattern indicates model bias. Simulated nitrate concentrations plotted with residuals for SD and SDPROB, with linear trend lines are shown in figure 8. Although both plots show a slight bias with increasing simulated nitrate concentrations, the SD model shows a more pronounced bias. This greater bias precludes the use of the SD nitrogen input model from further investigation. Maps showing the spatial distribution of residuals were analyzed; however, no spatial pattern was discernible.

Table 3. Comparison of the effectiveness of two nitrogen input layers in the subregional model using UCODE_2005 statistical results.

\begin{tabular}{lcc}
\hline & \multicolumn{2}{c}{ Nitrogen input updated from } \\
\cline { 2 - 3 } Model statistic & $\begin{array}{c}\text { Skinner and } \\
\text { Donato (2003) } \\
\text { (SD) }\end{array}$ & $\begin{array}{c}\text { Skinner and Donato } \\
\text { (2003) and prorated } \\
\text { with a probability } \\
\text { map (SDPROB) }\end{array}$ \\
\hline $\begin{array}{l}\text { UCODE optimized nitrogen } \\
\text { input multiplication factor }\end{array}$ & 232 & 392 \\
$\begin{array}{l}\text { Average weighted residual } \\
\text { Composite scaled sensitivity } \\
\text { (CSS) }\end{array}$ & 0.34 & 0.40 \\
$\begin{array}{l}\text { Least-squares objective } \\
\text { function }\end{array}$ & 1.90 & 1.97 \\
$\begin{array}{l}\text { Calculated error variance } \\
\text { (CEV) }\end{array}$ & 3.72 & $1,098.70$ \\
CEV 95-percent confidence \\
interval \\
$\begin{array}{l}\text { Standard Error (SE) } \\
\text { SE 95-percent confidence } \\
\text { interval }\end{array}$ & $3.21-4.36$ & $2.97-4.04$ \\
$\begin{array}{l}\text { Maximum likelihood } \\
\text { objective function }\end{array}$ & $1.79-2.09$ & $1.72-2.01$ \\
\hline
\end{tabular}


A. Nitrogen input model updated from Skinner and Donato (2003)

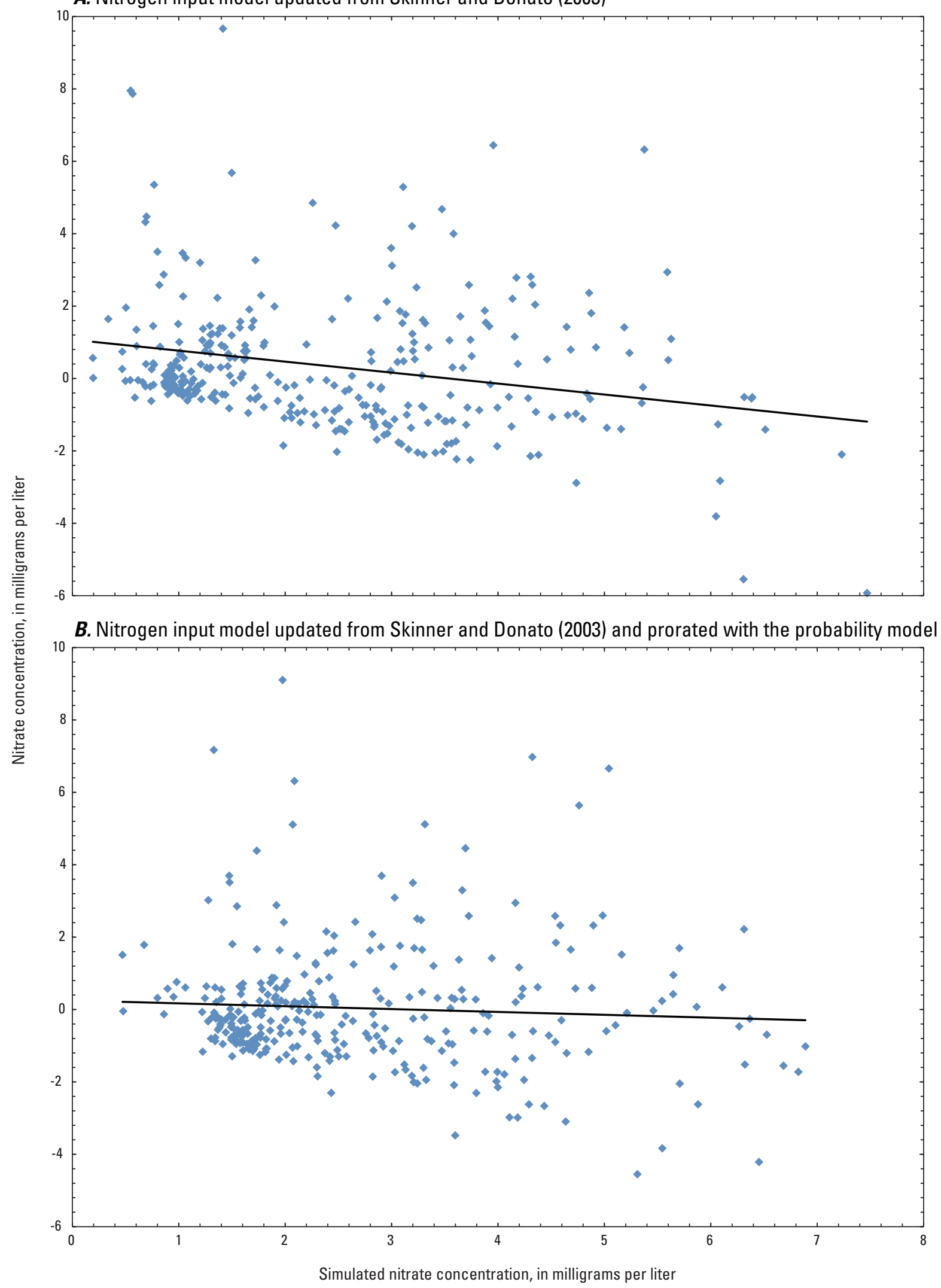

Figure 8. Simulated nitrate concentrations and corresponding model residuals with linear regression trend lines indicating model bias in $(A)$ nitrogen input model updated from Skinner and Donato (2003) (SD) and $(B)$ nitrogen input model updated from Skinner and Donato (2003) and prorated with a probability model (SDPROB). 


\section{Nitrate Transport in the Subregional Model and Particle-Tracking Results}

Transport modeling and particle tracking were used to simulate the movement, fate, and concentrations of nitrate in groundwater in the mid-Snake region of south-central Idaho under different nitrogen input scenarios. The nitrogen input layer, SDPROB, was used to estimate the spatial distribution and relative amount of nitrogen input to the water table, and the subregional model then simulated transport of nitrate through the aquifer system to the final discharge locations in the Thousand Springs area. The solute transport model was a useful tool for simulating present and future nitrate concentrations in the aquifer system. Particle tracking was a useful tool for visualizing the three-dimensional flow of nitrate through the aquifer system.

\section{Transport Modeling Results}

Nitrogen input from cattle manure has increased substantially in parts of the eastern Snake River Plain because the number of dairy cattle has increased five-fold from 1987 through 2007 (fig. 2). Fertilizer use also has increased during the same period as the result of crops such as feed corn grown to support the dairy industry (fig. 9; Ruddy and others, 2006;

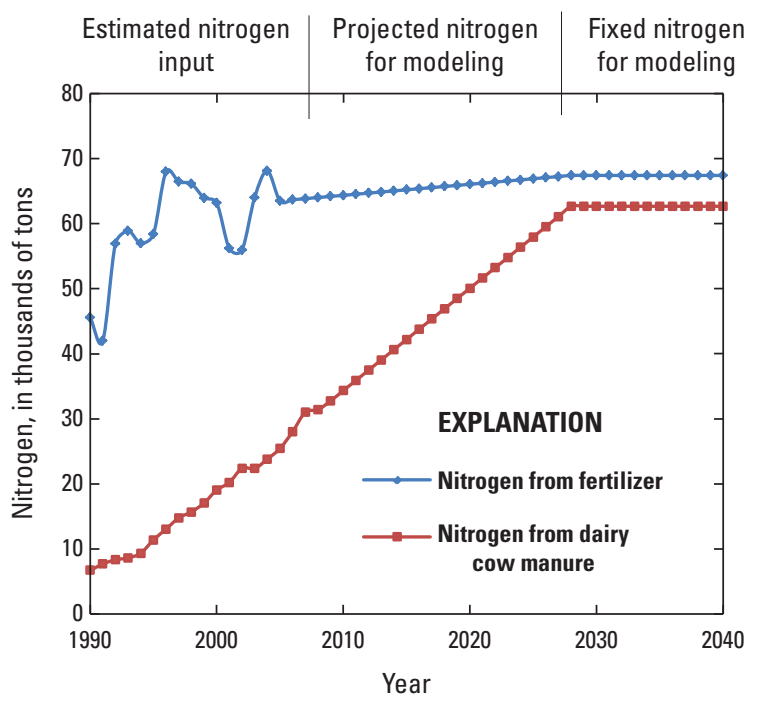

Figure 9. Nitrogen trends based on data collected during 1999-2008, south-central Idaho. Simulated nitrogen inputs to the subregional model were projected 20 years into the future from 2008, and then held constant from 2028 onward. Nitrogen input from dairy cows is projected to approach nitrogen input from fertilizer in about 20 years if trends continue as projected.
U.S. Department of Agriculture, 2010). The largest sources of nitrate in groundwater are chemical fertilizer and dairy cow manure applied to the land surface. Lesser contributions are from human waste, beef cow manure, decomposition of soil organic material, and atmospheric deposition (Rupert, 1996; Skinner and Donato, 2003).

Nitrate transport was simulated for 50 years starting in 2008, with three fertilizer and dairy manure nitrogen input scenarios:

- Scenario 1 estimates nitrogen input from fertilizer and dairy cows to 2008 levels based on U.S. Department of Agriculture county-level census data, and holds nitrogen input fixed at these levels to simulate the effects of current nitrogen input on nitrate concentrations in groundwater over time.

- Scenario 2 uses a linear projection of nitrogen input based on the previous 10 years (1998-2008) of fertilizer and dairy manure input for the model area (fig. 9) to project nitrogen input 20 years into the future. After 2028, nitrogen input is fixed at 2028 levels. This scenario examines long-term effects using best estimates of projected nitrogen input.

- Scenario 3 has zero local anthropogenic nitrogen input; all nitrogen input from fertilizer and dairy manure is halted completely, with only nitrogen input from precipitation remaining. This scenario is not likely to occur, but provides an estimate of how long it would take nitrate in groundwater to return to background concentrations - the "flushing time" of the system.

Scenario 1 simulates the effects of constant nitrogen input set at 2008 levels, which is the date of the most recent agricultural census. Although nitrogen input is held constant, nitrate concentrations in the groundwater continue to increase from 10 to 50 years after 2008, depending on the location in the model area (fig. 10).

Scenario 2 uses the previous 10 years of county fertilizer and dairy cattle nitrogen input to project linearly (ig. 9) the change in nitrogen input through the year 2028, after which the nitrogen input is constant. Although nitrogen input is held constant after the year 2028, groundwater nitrate concentrations continue to increase from 10 to 50 years into the future depending on the location in the model area (figs. 10 and $\underline{11}$ ).

Scenario 3 involves the cessation of all local anthropogenic nitrogen input to the system. Although stopping all local anthropogenic input is not a realistic scenario, it provides insight to how long it would take the aquifer system to discharge the residual nitrate to the Thousand Springs region and to return to background conditions. The models indicate that it will take from 20 to 50 years for the aquifer system to return to background conditions (fig. 11). The length of time depends on the location in the model area. 

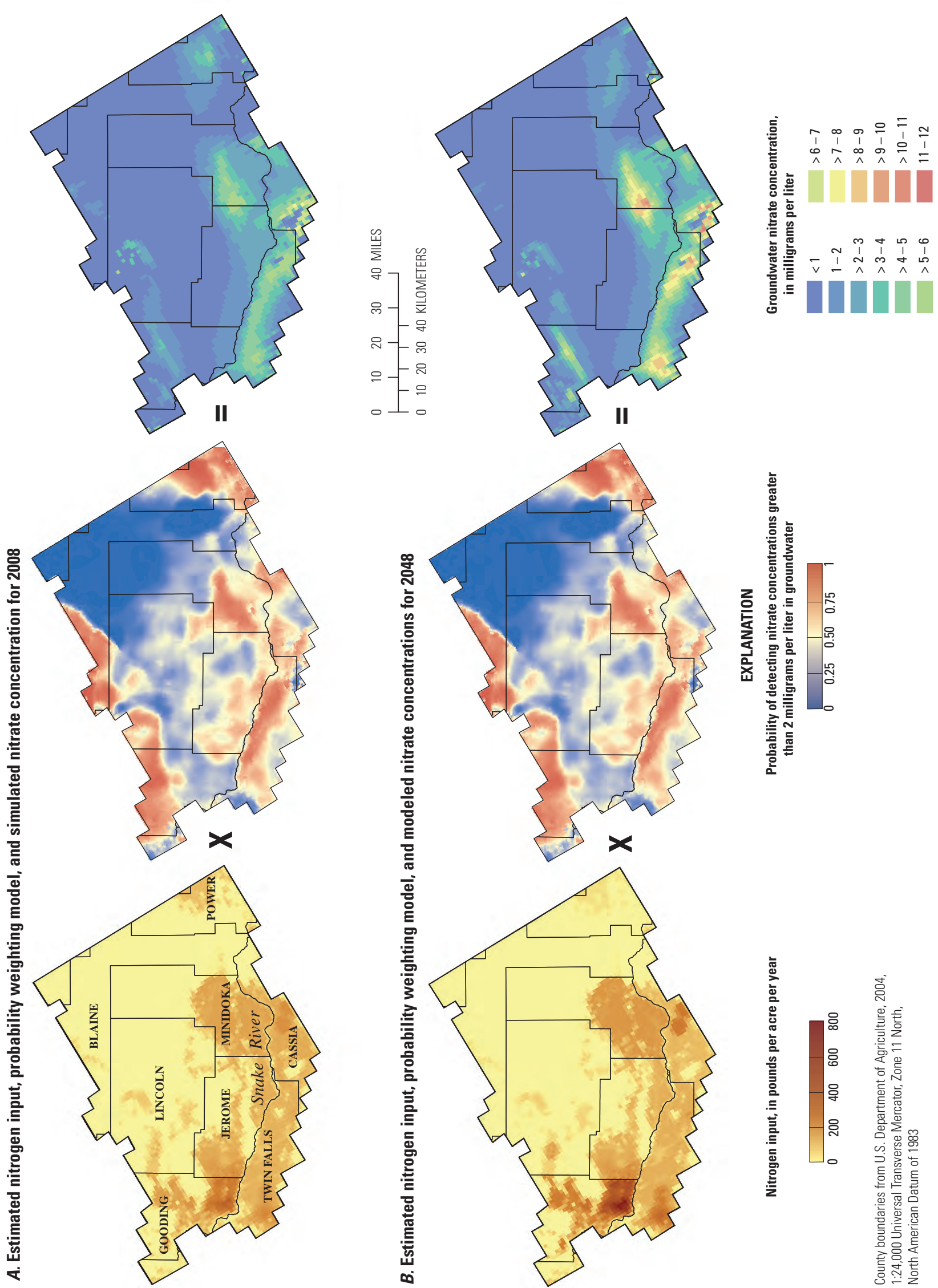

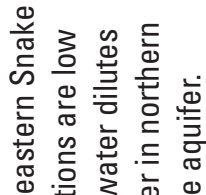

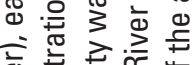

娄

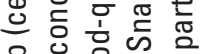

ॠ

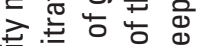

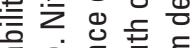

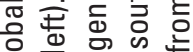

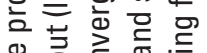

吉 을 元

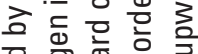

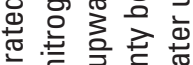

흔

흔 웡

응
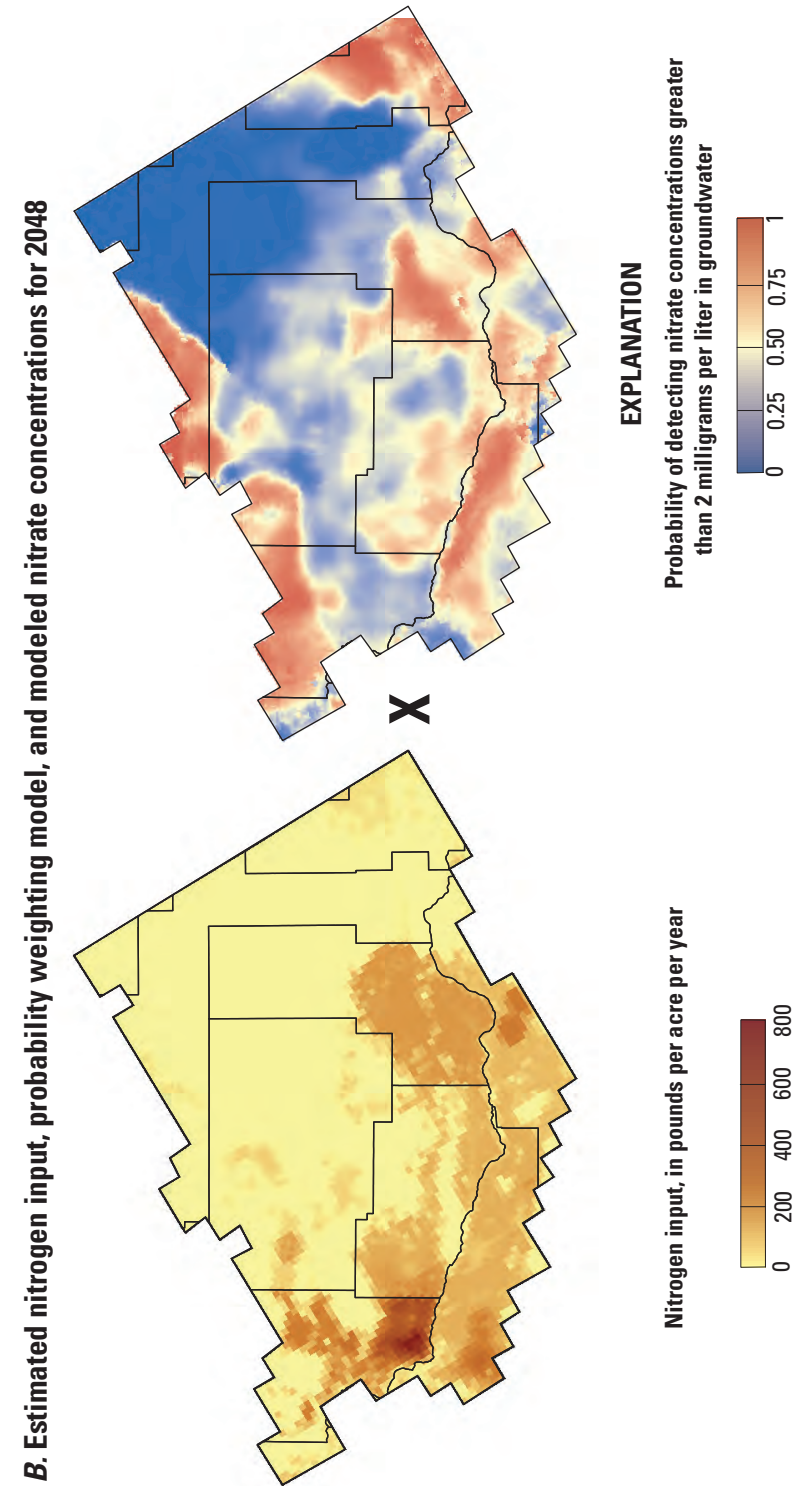

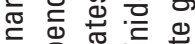

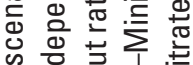

글을

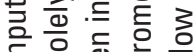

竞

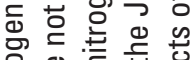

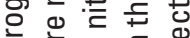

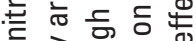

흥 등

$\Phi$

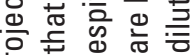

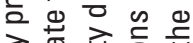

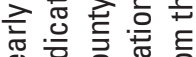

号.

ह

은 흉ㅎㅇ 등

豆离心

는 등 흘 음

世记

उ

产 亭 品

흔 옹을

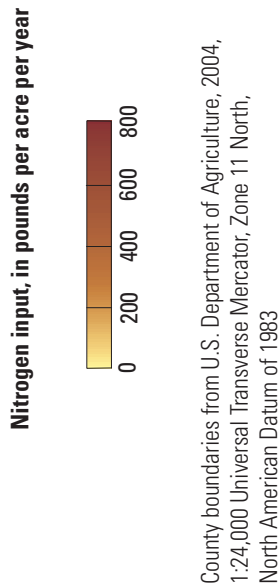

䒕 部

भ

的䒕

○

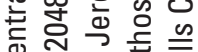

은 $\subseteq . \cong$

드ㅇㅝㅔ

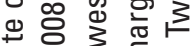

즌 든

늗

등 증 힝ㅎㅀ

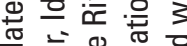

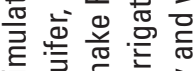

क वे के

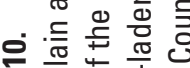

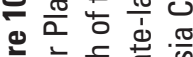

言高高离离离 


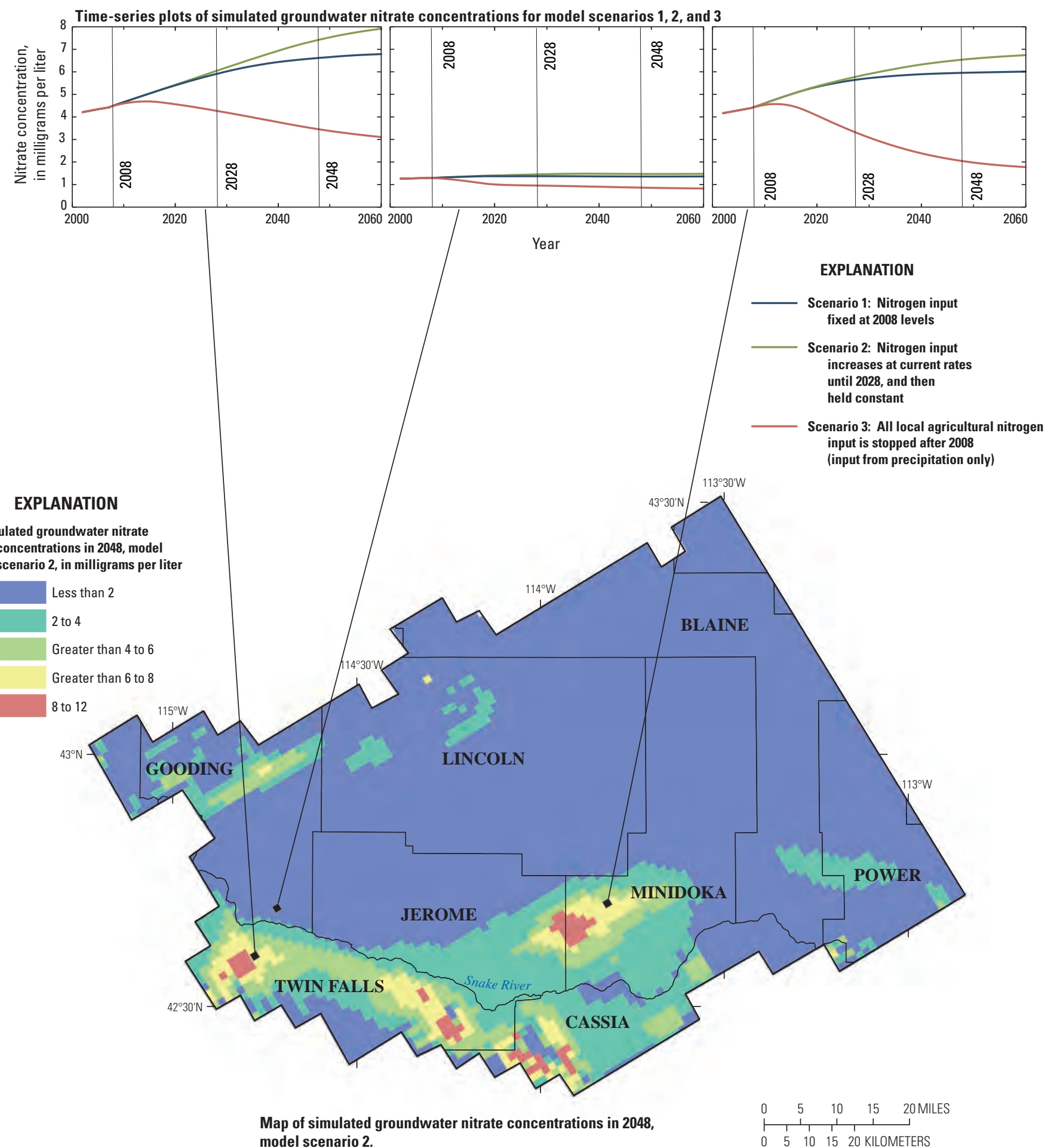

Figure 11. Simulated nitrate concentrations in 2048 and time-series plots for three locations in the Snake River Plain aquifer, southcentral Idaho. Estimated nitrate concentrations were as much as 11 milligrams per liter, using projected nitrogen input from scenario 2. Concentrations increase for as many as 50 years even though nitrogen input is held constant after 2028. With nitrogen input held constant at 2008 levels (scenario 1), the time response is similar, but concentrations level out at lower values. If local anthropogenic nitrogen input is halted in the model (scenario 3; improbable, but useful for judging system response time), it also takes much of the 21st century for nitrate to decline to a background concentration of less than 1 milligram per liter. 
Simulation estimations indicate that it will take decades for nitrate concentrations from groundwater in the Snake River Plain to respond to the full effects of changes in nitrogen input (fig. 11). Even if nitrogen input were held constant at 2008 values (scenario 1), it would take about 40 years (around 2048) for nitrate concentrations to begin to level off. It takes about 50 years for concentrations to stabilize for the projected and 2008-fixed nitrogen input scenarios 1 and 2, with scenario 2 stabilizing at higher values corresponding to the larger quantities of nitrogen in the projected scenario compared to 2008 levels. North of the Snake River in south Gooding County (upper middle graph), nitrate concentrations are kept low by upward convergence of low-nitrate concentration of regional groundwater that mixes with shallow, nitrate-laden groundwater.

Model simulation results for current (2008) conditions and for future (2048) groundwater nitrate conditions are shown in figure 11. In both cases, nitrate concentrations are low (less than 2 milligrams per liter) north of the Snake River in western Jerome County and southern Gooding County, despite high nitrogen input rates in those areas. Simulation results indicate that the nitrogen input layer was not necessarily the overall driving factor in resulting nitrate concentrations; rather, aquifer thinning near its terminus and the resulting upwelling of low-nitrate regional groundwater (section "Particle-Tracking Simulations") help explain the long-standing dilemma of how groundwater nitrate concentrations can remain low in much of Jerome and Gooding Counties despite large quantities of nitrogen input from fertilizer and cattle manure (fig. 10).

In contrast, simulated nitrate concentrations are high south of the Snake River in Cassia County and in western Twin Falls County. Although the aquifer is thin in these areas, there is little to no upwelling of good-quality groundwater from deeper parts of the aquifer, so groundwater quality is influenced by recharge of nitrate-laden irrigation water. Nitrate concentrations south of the Snake River are forecast to rise above the U.S. Environmental Protection Agency maximum contaminant level for drinking water of $10 \mathrm{mg} / \mathrm{L}$ by 2048 under the nitrogen-input scenario 2. Nitrate concentrations in groundwater throughout the model area were simulated to increase by as much as 2 to $4 \mathrm{mg} / \mathrm{L}$ under projected nitrogen input estimates for scenario 2, with some areas reaching or exceeding $10 \mathrm{mg} / \mathrm{L}$ (igs. 10 and $\underline{11}$ ).

\section{Particle-Tracking Simulations}

Forward and backward particle-tracking simulations using the subregional model (Clark and others, 2006) were performed using MODPATH (Pollock, 1994) to visualize groundwater flow directions and velocities. For the first simulation (fig. 12), one particle was placed in the middle of each grid cell in layer 1 of column 96 (easternmost column of the model), and MODPATH was run forward to completion.
The particles moved roughly east to west across the Snake River Plain until they discharged into the Snake River in the Thousand Springs area. Much of groundwater flowing from the east edge of the model area primarily runs beneath rangeland (fig. 12), and does not flow beneath agricultural lands until it reaches Jerome and Gooding Counties on the western part of the model area. Nitrate concentrations in groundwater are at background concentrations of less than $1 \mathrm{mg} / \mathrm{L}$ until they flow beneath the agricultural areas of Jerome and Gooding Counties (Rupert, 1997, fig. 21).

Elevated nitrate concentrations have been measured in groundwater in the local alluvial aquifer and in groundwater north of the local perched aquifer in the southern part of Minidoka County (Young and others, 1987b; Rupert, 1994; Crockett, 1995; Rupert and others, 1996; Rupert, 1997). Groundwater with elevated nitrate concentrations could be leaching from the local alluvial aquifer vertically to the regional basalt aquifer. Rupert (1997, p. 8) reported that groundwater in the local alluvial aquifer generally flows northward and westward, indicating that groundwater also could be "spilling" off the sides of the local perched aquifer on the north and west margins downward to the regional basalt aquifer below. To track the flow direction of the groundwater with elevated nitrate concentrations, one particle was placed in the top of each cell located beneath the local alluvial aquifer (fig. 13), and the particles were tracked until they exited from the subregional model as spring discharge to the Snake River. Most groundwater exited the subregional model at Blue Lakes Spring (see cover photograph). These pathlines indicate that the groundwater originates and flows beneath intensely cultivated cropland, and the elevated nitrate concentrations reflect large nitrogen input from agricultural activities. This increase in nitrate concentrations is due to fertilizer-enriched groundwater recycled through multiple pumping and irrigation cycles (Rupert, 1997).

Most groundwater in the eastern Snake River Plain discharges to the Snake River from large springs between Milner Dam and King Hill. Some of these springs are large enough to generate hydropower and to support large fish hatcheries. Combined discharge in this reach was about 6,000 ft³/s during 1980 (Kjelstrom, 1992, p. 2). Backward particle tracking from these large springs was used to observe groundwater flow paths in relation to the overlying land use and recharge locations. Backward particle tracking was calculated by placing one particle in the middle of each cell where a spring was located and letting the model run for 100 years (fig. 14). Square, black boxes are shown on each particle pathline at 1-year intervals to indicate groundwater flow velocities, which are reflected in the distance between the boxes (more distance means greater groundwater velocity). Pathlines that underlie the greatest proportion of irrigated agricultural lands correspond with elevated nitrate concentrations measured by Young and others (1987a, 1987b), Rupert (1994), Rupert and others (1996), and Rupert (1997). 


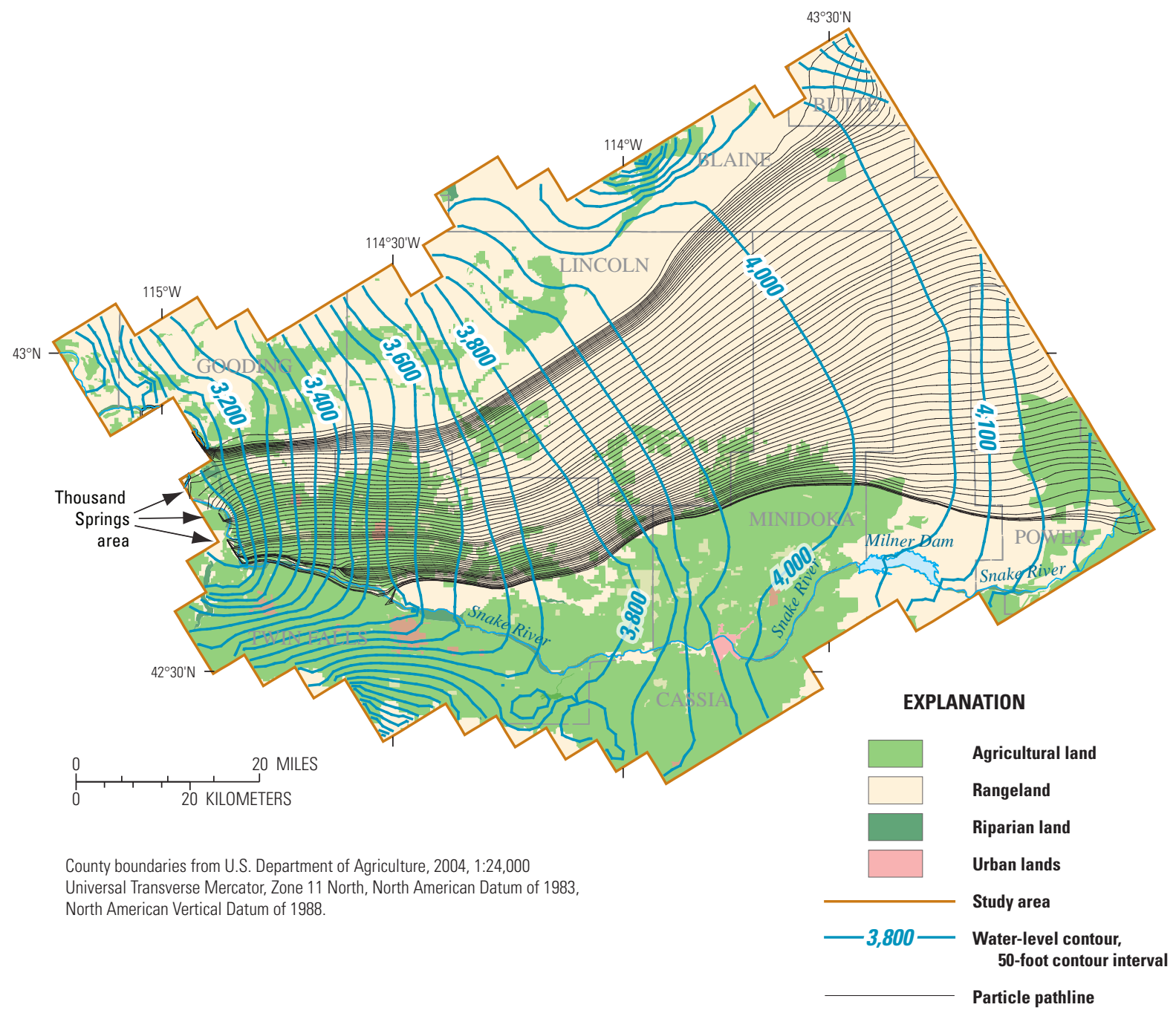

Figure 12. Forward particle-tracking simulation starting in the easternmost column of model cells of the subregional model, south-central Idaho. Particles began in the middle of layer 1, column 96 , the easternmost column of model cells. Particles were tracked until exiting the model as spring discharge to the Snake River in the Thousand Springs area. 


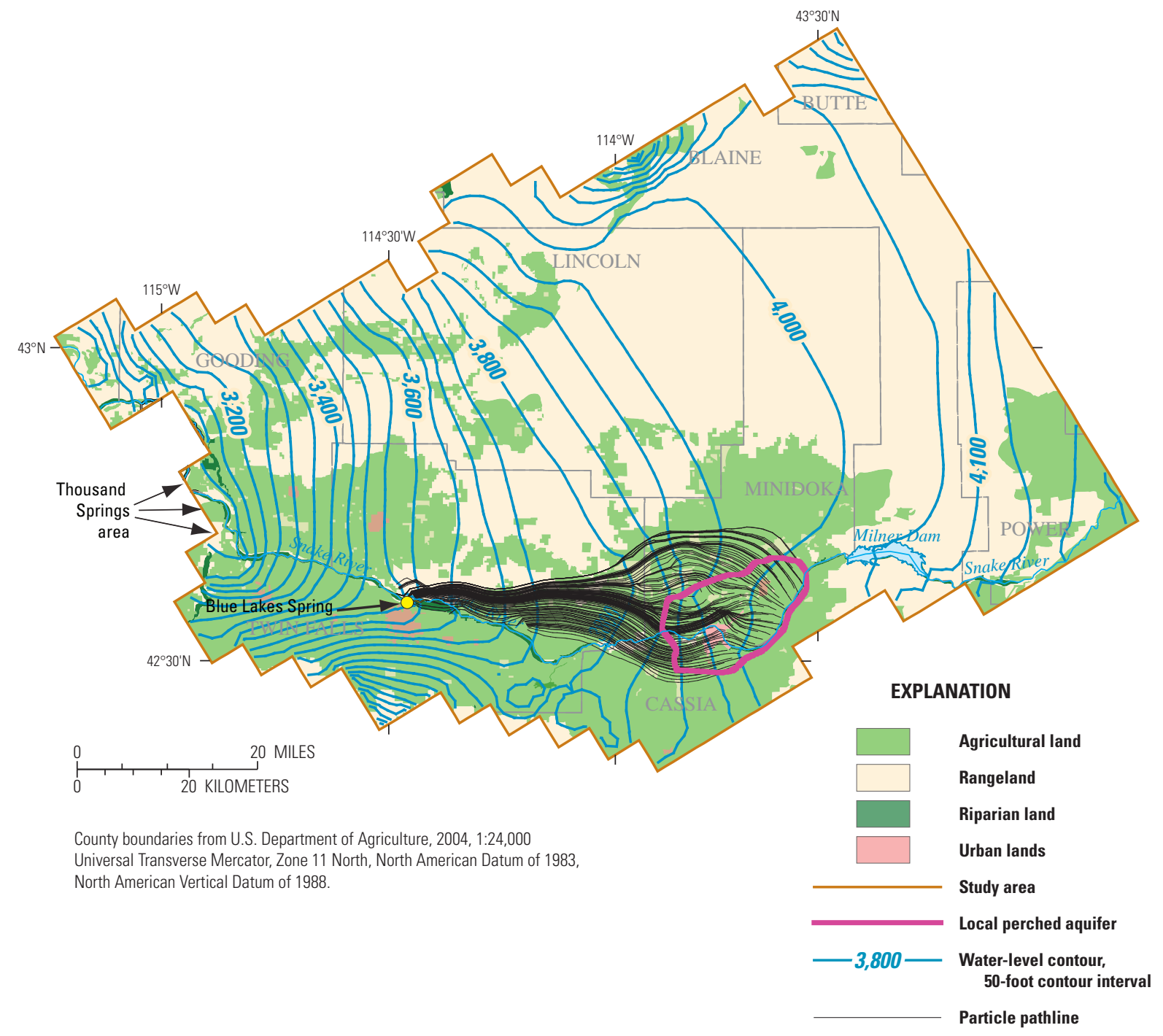

Figure 13. Forward particle-tracking simulation starting in the local perched aquifer of the subregional model, south-central Idaho. Particles were tracked generally northward and westward until they exited the model as spring discharge to the Snake River from Blue Lakes Springs. 


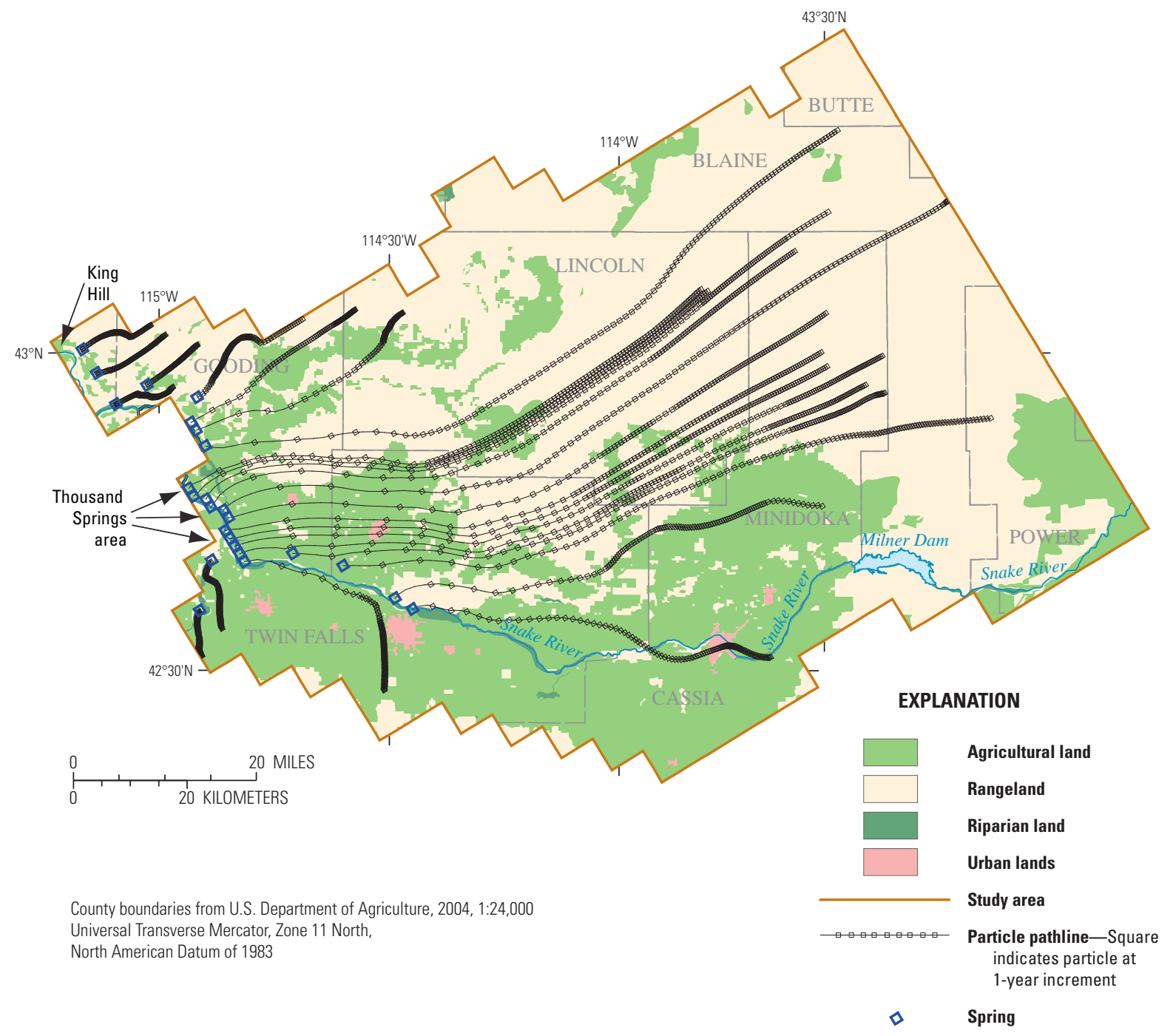

Figure 14. Backward particle tracking simulation in the subregional model, south-central Idaho. Particles began in each large spring in the Thousand Springs area and traveled backward for 100 years.

This pattern is obvious particularly in nitrate concentrations downgradient of agricultural areas in southwest Minidoka County, but much less apparent downgradient of agricultural areas in southern Jerome and Gooding Counties. The difference between the amounts of increased nitrate cannot be explained solely by the difference in nitrogen input; in fact, nitrogen input in the Jerome County and Gooding County agricultural areas is estimated to be much greater than input in the other areas because of more dairies and associated agriculture and, therefore, greater nitrogen input (fig. 9).

The geometry of the aquifer and the pattern of regional groundwater flow through the aquifer greatly influences nitrate concentrations (fig. 15). The eastern Snake River Plain aquifer is estimated to reach a maximum saturated thickness of about 4,000 ft in the central part of the plain, from which the aquifer thins to the west. Thinning of the aquifer forces upward convergence of regional groundwater, much of it having originated as good-quality, mountain-front recharge along the north margin of the plain or as recharge through undeveloped rangeland. The flow convergence also coincides with the observed steepening of the water table, as the entire aquifer flow is funneled through an increasingly thinner aquifer toward discharge areas along the Snake River, most notably in the Thousand Springs area. Good-quality regional water converges upward and mixes with the nitrate-laden groundwater in the uppermost parts of the aquifer (fig. 15), and then discharges to the Snake River in the Thousand Springs area. This hypothesis of flow-system control on water quality is supported by measured nitrate concentrations in wells located near agricultural areas and the subregional model simulation results. 


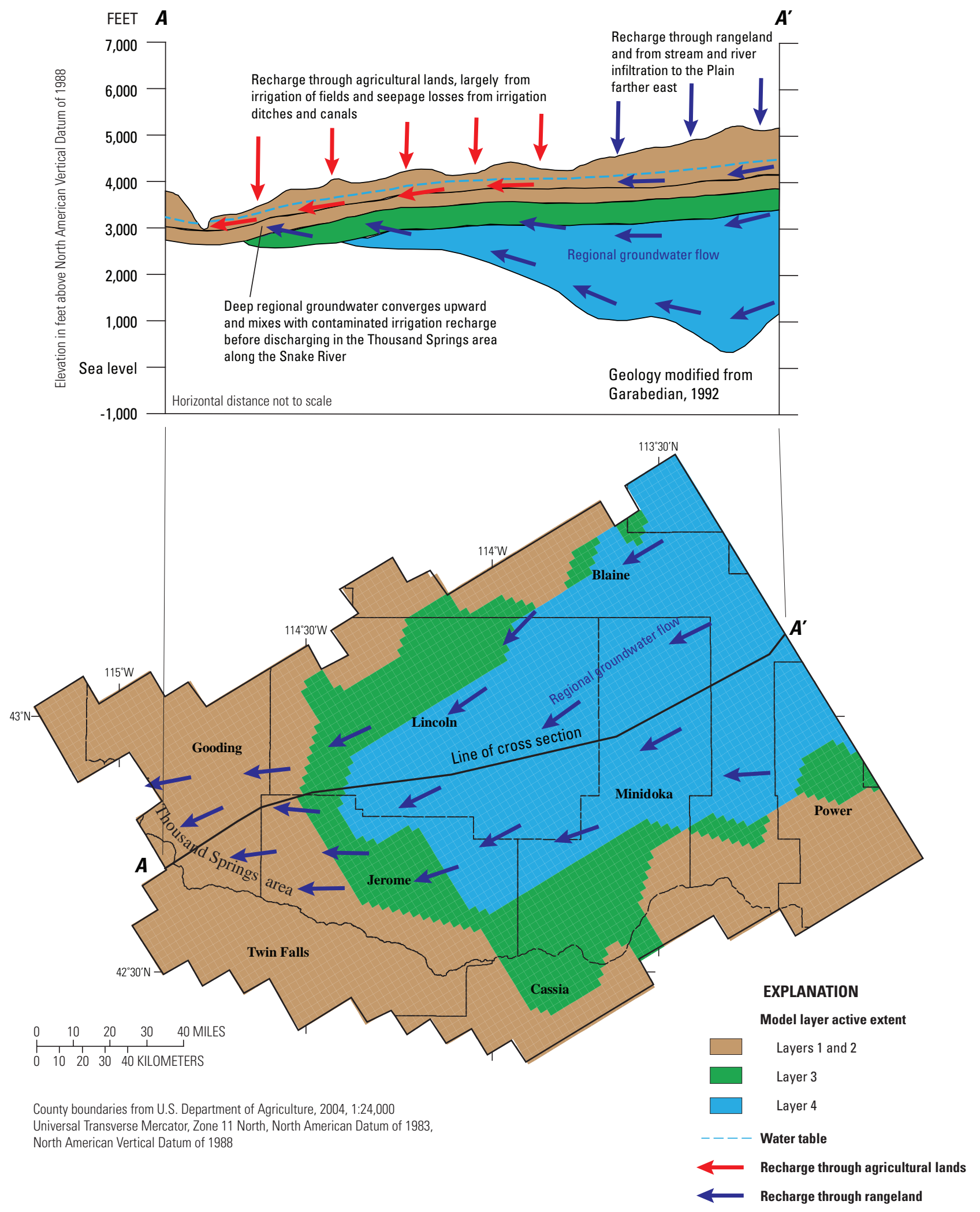

Figure 15. The eastern Snake River Plain aquifer thins to the west toward the Thousand Springs area, south-central Idaho. Good-quality regional groundwater converges upward and mixes with nitrate-laden irrigation recharge from overlying agricultural lands in west Jerome and south Gooding Counties, where nitrate concentrations in water samples collected from wells are low despite large amounts of nitrogen input from fertilizers and cattle manure. 


\section{Model Use, Guidance, and Limitations}

The subregional model used for this study is intended for large-scale, nitrate-transport simulations. The model lacks sufficient details for small-scale applications such as modeling the effects on individual farms or dairies. The accuracy of the model is limited because of the simplifying assumptions used, model parameter uncertainties, and the relatively large size of the grid cells. These limitations must be understood and considered when applying the model to resource-management issues. The nitrogen-input data from cattle manure and fertilizer are general values representing large areas (counties). Small spatial changes in land use or nitrogen input cannot be simulated effectively with the subregional model; however, the model is well suited for assessing county-based nutrient management plans.

The greatest limitations in using the subregional model for this study are the assumptions inherent in the model. These assumptions are carried forward cumulatively from each model version. The model assumption that likely affects model accuracy the most is the early timeframe. Since the development of the eastern Snake River Plain model (Garabedian, 1992), the flow system has undergone a decrease in recharge from an extended drought, changes in land use, and more efficient irrigation methods. A decrease in flow through the system would result in longer travel times and altered mixing rates between local and regional groundwater flow.

\section{Summary}

Groundwater provides most of the drinking water in Idaho, and groundwater quality is an ongoing concern because of rising nitrate concentrations in an increasing number of wells. The predominant sources of nitrate throughout much of the State are inorganic fertilizer, cattle manure, and legume crops. Increasing nitrate concentrations are of particular concern in the mid-Snake region of south-central Idaho because the region is experiencing substantial growth in some agricultural industries associated with the discharge of nitrogen to the environment. Along with the increase in dairy cattle, fertilizer use also has increased during the same time as the result of an increase in crops such as feed corn grown to support the dairy industry. The current and future effect of expanded agriculture on groundwater quality in this area is not fully understood. In response to these concerns and needs, the U.S. Geological Survey conducted this investigation in the mid-Snake region of south-central Idaho.

To assess current and future nitrate concentrations in groundwater in the Mid-Snake region, nitrate concentrations in groundwater were simulated using an existing threedimensional subregional groundwater transport model. A statistical model that estimated the probability of groundwater contamination from elevated nitrate concentrations was developed using logistic regression techniques and was incorporated into the subregional model to assist nitrogen input to the subregional model. The subregional model simulated the change of nitrate concentrations in groundwater over time in response to three nitrogen input scenarios: (1) nitrogen input fixed at 2008 levels; (2) nitrogen input increased from 2008 to 2028 using the same rate of increase as the average rate of increase observed during the previous 10 years (1998-2008); after 2028, nitrogen input was fixed at 2028 levels; and (3) nitrogen input related to local agriculture completely halted, with only nitrogen input from precipitation remaining.

Geographic Information System data on nitrate concentrations in groundwater, depth to groundwater, groundwater velocity, total nitrogen input from dairies, total nitrogen input from fertilizer, percent land use, precipitation, and soils were compiled to provide data for the groundwater nitrate probability model. Upgradient 90-degree, wedgeshaped zones of influence were calculated for each well where groundwater-quality data were collected to determine either the sum or the average for nitrogen input, land use, and soils properties upgradient of each sampled well. The optimum size for each wedge-shaped zone was calculated using groundwater age and groundwater flow velocity. The logistic model had statistically significant independent variables of depth to groundwater, soil available water capacity, soil liquid limit, soil depth to bedrock within soil horizon, and precipitation. The logistic regression model was verified by plotting the percentage of actual detections with the predicted probability of detections using deciles of risk. An R-squared value of the plot of actual detections with the predicted probability of detections was 0.998 , verifying the high effectiveness of the model. A new method was used to determine nitrogen input to a subregional groundwater transport model. A map predicting the probability of nitrate concentrations greater than $2 \mathrm{mg} / \mathrm{L}$ in groundwater was used to prorate estimated nitrogen input to the subregional model.

Two nitrogen input layers for the subregional model are evaluated in this report. The first nitrogen input layer is the one used by Skinner and Donato (2003). The second nitrogen input layer is the same as the Skinner and Donato (2003) input layer, but modified using a map of the probability of elevated nitrate concentrations to prorate nitrogen input to groundwater. The probability map ratings range from close to zero (very low probability of nitrate concentrations greater than $2 \mathrm{mg} / \mathrm{L}$ in groundwater) to close to one (very high probability of nitrate concentrations greater than $2 \mathrm{mg} / \mathrm{L}$ in groundwater). By multiplying the Skinner and Donato nitrogen input by the probability ratings, areas with low probability ratings would have a reduced nitrogen input, and areas with high probability ratings would maintain the level of nitrogen input corresponding to the Skinner and Donato (2003) nitrogen input layer. Because the probability map ratings are based on correlations with physical factors, the probability-mapmodified, nitrogen-input layer incorporates a much more realistic estimate of nitrogen flux to the water table than Skinner and Donato (2003). 
The effectiveness of the two nitrogen input layers was tested by estimating a multiplication factor, applied to each input layer, and comparing overall model fit statistics. This analysis indicated that nitrogen input estimated using the probability map more accurately represents the measured nitrate concentrations than the Skinner and Donato (2003) nitrogen input layer. Residual analysis indicates less bias in the probability-modified subregional model than without the probability modification, further proving it is a more effective model than the Skinner and Donato (2003) nitrogen input layer.

The nitrate-transport model simulation results indicate that, even when the nitrogen input is held constant, nitrate concentrations in the groundwater continue to increase for 10 to 50 years after 2008 , depending on the location in the model area. It takes decades for nitrate concentrations in groundwater in the mid-Snake region to respond completely to changes in nitrogen input. If nitrogen input to the mid-Snake region keeps increasing as it has for the past 10 years, some areas in Cassia, Minidoka, and Twin Falls Counties are estimated to exceed the U.S. Environmental Protection Agency maximum contaminant level for drinking water of 10 milligrams per liter. North of the Snake River in southern Gooding and western Jerome Counties, nitrate concentrations are low because the shallow, nitrate-laden groundwater mixes with low-nitrate groundwater that is upwelling from deeper parts of the aquifer. Nitrate concentrations in groundwater are simulated to increase by as much as 2 to 4 milligrams per liter in many areas, with nitrate concentrations in some areas reaching or exceeding 10 milligrams per liter.

Particle-tracking simulations show that groundwater pathlines underlying the greatest proportion of irrigated agricultural lands correspond with elevated nitrate concentrations. This pattern is obvious particularly in nitrate concentrations downgradient of agricultural areas in southwest Minidoka County, but much less apparent downgradient of southern Jerome and Gooding County agricultural areas. The difference between the quantities of increased nitrate cannot be explained solely by difference in nitrogen input; in fact, nitrogen input in the Jerome and Gooding County agricultural areas is estimated to be greater than that in the other areas because more dairies and associated agriculture are in the area and, therefore, greater nitrogen input. The geometry of the aquifer and the pattern of regional groundwater flow through the aquifer greatly influences nitrate concentrations. Thinning of the aquifer forces upward convergence of regional, goodquality groundwater that also coincides with the observed steepening of the water table, as the entire aquifer flow is funneled through an increasingly thinner aquifer toward discharge areas along the Snake River in the Thousand Springs area. Good-quality regional water converges upward and mixes with the nitrate-laden groundwater in the uppermost parts of the aquifer, resulting in lowered nitrate concentrations in groundwater.

\section{References Cited}

Ackerman, D.J., 1995, Analysis of steady-state flow and advective transport in the eastern Snake River Plain aquifer system, Idaho: U.S. Geological Survey Water-Resources Investigations Report 94-4275, 25 p. (Also available at http://pubs.er.usgs.gov/publication/wri944257.)

Clark, D.W., Skinner, K.D., and Pollock, D.W., 2006, A graphical modeling tool for evaluating nitrogen loading to and nitrate transport in ground water in the midSnake Region, south-central Idaho: U.S. Geological Survey Scientific Investigations Report 2006-5137, 32 p. (Also available at http://pubs.er.usgs.gov/publication/ sir20065137.)

Clark, G.M., and Ott, D.S., 1996, Springflow effects on chemical loads in the Snake River, South-Central Idaho: Journal of the American Water Resources Association, v. 32, no. 3, p. 553-563.

Cosgrove, D.M., Johnson, G.S., Laney, S., and Lindgren, J., 1999, Description of the Snake River Plain Aquifer Model (SRPAM): Moscow, Idaho, University of Idaho, Idaho Water Resources Research Institute, 101 p.

Crockett, J.K., 1995, Idaho Statewide Ground Water Quality Monitoring Program-Summary of results, 1991 through 1993: Idaho Department of Water Resources Water Information Bulletin no. 50, pt. 2, 67 p.

Daly, Christopher, Neilson, R.P., and Phillips, D.L., 1994, A statistical-topographic model for mapping climatological precipitation over mountainous terrain: Journal of Applied Meteorology, v. 33, p. 140-158, accessed May 3, 2012, at http://www.prism.oregonstate.edu/docs/index.phtml. Geospatial data accessed May 3, 2012, at http://www.prism. oregonstate.edu/products/viewer.phtml?file=/pub/prism/ us 30s/grids/ppt/Normals/us ppt 1971 2000.14.gz\&year= $19712000 \&$ vartype $=$ ppt\&month $=14 \&$ status $=$ final.

Eckhardt, D.A.V., and Stackelberg, P.E., 1995, Relation of groundwater quality to land use on Long Island, N.Y.: Ground Water, v. 33, no. 6, p. 1019-1033.

Environmental Systems Research Institute, Inc., 2011, ArcGIS Desktop Help 10.0-How spline with barriers works: Environmental Systems Research Institute, Inc., Web site, accessed May 3, 2012, at http://help.arcgis.com/en/ arcgisdesktop/10.0/help/index.html\#/How Spline with Barriers works/009z00000079000000/.

Frans, L.M., Rupert, M.G., Hunt, C.D., Jr., and Skinner, K.D., 2012, Groundwater quality in the Columbia Plateau, Snake River Plain, and Oahu basaltic-rock and basin-fill aquifers in the northwestern United States and Hawaii, 1992-2010: U.S. Geological Survey Scientific Investigations Report 2012-5123, 84 p. 
Garabedian, S.P., 1992, Hydrology and digital simulation of the regional aquifer system, eastern Snake River Plain, Idaho: U.S. Geological Survey Professional Paper 1408-F, 102 p., 10 pls. (Also available at http://pubs.er.usgs.gov/ publication/pp1408F.)

Gurdak, J.J., 2008, Groundwater vulnerability—Nonpoint source contamination, climate variability, and the High Plains aquifer: Saarbrucken, Germany, VDM Verlag Publishing, ISBN: 978-3-639-09427-5, 223 p.

Gurdak, J.J., McCray, J.E., Thyne, G.D., and Qi, S.L., 2007, Latin hypercube approach to estimate uncertainty in ground water vulnerability: Ground Water, v. 45, no. 3, p. 348-361, doi: 10.1111/j.1745-6584.2006.00298.x.

Gurdak, J.J., and Qi, S.L., 2006, Vulnerability of recently recharged ground water in the High Plains aquifer to nitrate contamination: U.S. Geological Survey Scientific Investigations Report 2006-5050, 39 p. (Also available at http://pubs.er.usgs.gov/publication/sir20065050.)

Harbaugh, A.W., Banta, E.R., Hill, M.C., and McDonald, M.G., 2000, MODFLOW-2000, the U.S. Geological Survey modular groundwater model — User guide to modularization concepts and the ground-water flow process: U.S. Geological Survey Open-File Report 2000-92, 121 p. (Also available at http://pubs.er.usgs.gov/publication/ofr200092.)

Harbaugh, A.W., and McDonald, M.G., 1996, User’s documentation for MODFLOW-96, an update to the U.S. Geological Survey modular finite-difference ground-water flow model: U.S. Geological Survey Open-File Report 96-485, 56 p.

Harbaugh, A.W., and McDonald, M.G., 1996, Programmer's documentation for MODFLOW-96, an update to the U.S. Geological Survey modular finite-difference ground-water flow model: U.S. Geological Survey Open-File Report 96-486, 220 p.

Helsel, D.R., and Hirsch, R.M., 1992, Statistical methods in water resources: New York, Elsevier Science Publishing Company, Inc., 522 p.

Hill, M.C., and Tiedeman, C.R., 2007, Effective groundwater model calibration: Hoboken, N.J., John Wiley \& Sons, Inc., $455 \mathrm{p}$.

Hosmer, D.W., and Lemeshow, Stanley, 1989, Applied logistic regression: New York, John Wiley \& Sons, Inc., 307 p.

Idaho Agricultural Statistics Service, 1999, Idaho Agricultural Statistics: Idaho State Department of Agriculture, 65 p.

Idaho Department of Water Resources, 2009, Irrigation Companies: Idaho Department of Water Resources database, accessed May 3, 2012, at http://www.idwr.idaho. gov/GeographicInfo/GISdata/irrigation.htm.
Idaho Department of Water Resources, 2011, Eastern Snake Plain Aquifer model: Idaho Department of Water Resources Web site, accessed May 3, 2012, at http://www.idwr.idaho. gov/WaterInformation/Projects/espam/.

Jaccard, James, 2001, Interaction effects in logistic regression: Thousand Oaks, Calif., Sage Publications, Inc., 70 p.

Kipp, K.L., Jr., Konikow, L.F., and Hornberger, G.Z., 1998, An implicit dispersive transport algorithim for the U.S. Geological Survey MOC3D solute-transport model: U.S. Geological Survey Water-Resources Investigations Report 98-4234, 54 p. (Also available at http://pubs.er.usgs.gov/ publication/wri984234.)

Kjelstrom, L.C., 1992, Assessment of spring discharge to the Snake River, Milner Dam to King Hill, Idaho: U.S. Geological Survey Water Fact Sheet, Open-File Report 92-147, 2 p. (Also available at http://pubs.er.usgs.gov/ publication/ofr92147.)

Kjelstrom, L.C., 1995, Streamflow gains and losses in the Snake River and ground-water budgets for the Snake River plain, Idaho and eastern Oregon: U.S. Geological Survey Professional Paper 1408-C, 47 p. (Also available at http:// pubs.er.usgs.gov/publication/pp1408C.)

Kleinbaum, D.G., 1994, Logistic regression, a self-learning text: New York, Springer-Verlag, 282 p.

Knutson, C.F., McCormick, K.A., Crocker, J.C., Glenn, M.A., and Fishel, M.L., 1992, 3D RWMC vadose zone modeling (including FY-89 to FY-90 basalt characterization results): EG and G Idaho, Inc., Report EGG-ERD-10246 [variously paged].

Knutson, C.F., McCormick, K.A., Smith, R.P., Hackett, W.R., O’Brien, J.P., and Crocker, J.C., 1990, FY-89 RWMC vadose zone basalt characterization: EG and G Idaho, Inc., Report EGG-WM-8949 [variously paged].

Konikow, L.F., Goode, D.L., and Hornberger, G.Z., 1996, A three-dimensional method of characteristics solute-transport model (MOC3D): U.S. Geological Survey Water-Resources Investigations Report 96-4267, 87 p. (Also available at http://pubs.er.usgs.gov/publication/wri964267.)

LaMotte, Andrew, 2008, National Land Cover Database 2001 (NLCD01) Tile 1, Northwest United States—NLCD01_1: U.S. Geological Survey Data Series Report DS-383A, accessed May 3, 2012, at http://water.usgs.gov/GIS/ metadata/usgswrd/XML/nlcd01_1.xml .

Lindholm, G.F., 1996, Summary of the Snake River Plain Regional Aquifer-System Analysis in Idaho and eastern Oregon: U.S. Geological Survey Professional Paper 1408-A, 59 p., 1 pl. (Also available at http://pubs.er.usgs. gov/publication/pp1408A.) 
Lorenz, D.L., Goldstein, R.M., Cowdery, T.K., and Stoner, J.D., 2003, Comparison of two methods for delineating land use near monitoring wells used for assessing quality of shallow ground water: U.S. Geological Survey WaterResources Investigations Report 2003-4067, 13 p. (Also available at http://pubs.er.usgs.gov/publication/wri034067.)

Mann, L.J., and Cecil, L.D., 1990, Tritium in ground water at the Idaho National Engineering Laboratory, Idaho: U.S. Geological Survey Water-Resources Investigations Report 90-4090, 35 p. (Also available at http://pubs.er.usgs.gov/ publication/wri904090.)

McDonald, M.G., and Harbaugh, A.W., 1988, A modular three-dimensional finite-difference ground-water flow model: U.S. Geological Survey Techniques of WaterResources Investigations, book 6, chap. A1, 586 p. (Also available at http://pubs.er.usgs.gov/publication/twri06A1.)

Moreland, J.A., Seitz, H.R., and LaSala, A.M., 1976, Effects of drain wells on the ground-water quality of the western Snake River Plain Aquifer, Idaho: U.S. Geological Survey Open-File Report 76-673, 83 p. (Also available at http:// pubs.er.usgs.gov/publication/ofr76673.)

Nolan, B.T., and Hitt, K.J., 2002, Nutrients in shallow ground waters beneath relatively undeveloped areas in the conterminous United States: U.S. Geological Survey Water-Resources Investigations Report 2002-4289, 17 p. (Also available at http://pubs.er.usgs.gov/publication/ wri20024289.)

Nolan, B.T., Hitt, K.J., and Ruddy, B.C., 2002, Probability of nitrate contamination of recently recharged groundwaters in the conterminous United States: Environmental Science and Technology, v. 36, no. 10, p. 2138-2145.

Parliman, D.J., and Young, H.W., 1987, Selected water-quality data for the Murtaugh Lake area, south-central Idaho, June 1987: U.S. Geological Survey Open-File Report 87-466, 1 sheet, scale 1:37,250. (Also available at http://pubs. er.usgs.gov/publication/ofr87466.)

Plummer, L.N., Rupert, M.G., Busenberg, E., and Schlosser, P., 2000, Age of irrigation water in ground water from the Eastern Snake River Plain Aquifer, south-central Idaho: Ground Water, March-April 2000, v. 38, no. 2, p. 264-283.

Poeter, E.P., Hill, M.C., Banta, E.R., Mehl, Steffen, and Christensen, Steen, 2005, UCODE_2005 and six other computer codes for universal sensitivity analysis, calibration, and uncertainty evaluation-constructed using the JUPITER API: U.S. Geological Survey Techniques and Methods, 6-A11, 299 p. (Also available at http://pubs. er.usgs.gov/publication/tm6A11.)
Pollock, D.W., 1989, Documentation of computer programs to compute and display pathlines using results from the U.S. Geological Survey modular three-dimensional finitedifference ground-water flow model: U.S. Geological Survey Open-File Report 89-381, 188 p. (Also available at http://pubs.er.usgs.gov/publication/ofr89381.)

Pollock, D.W., 1994, User's guide for MODPATH/ MODPATHPLOT, Version 3-A particle tracking postprocessing package for MODFLOW, the U.S. Geological Survey finite-difference ground-water flow model: U.S. Geological Survey Open-File Report 94-464, 248 p. (Also available at http://pubs.er.usgs.gov/publication/ofr94464.)

Ruddy, B.C., Lorenz, D.L., and Mueller, D.K., 2006, Countylevel estimates of nutrient inputs to the land surface of the conterminous United States, 1982-2001: U.S. Geological Survey Scientific Investigations Report 2006-5012, 22 p. (Also available at http://pubs.er.usgs.gov/publication/ sir20065012.)

Rupert, M.G., 1994, Analysis of data on nutrients and organic compounds in ground water in the upper Snake River Basin, Idaho and western Wyoming, 1980-91: U.S. Geological Survey Water-Resources Investigations Report 94-4135, 40 p. (Also available at http://pubs.er.usgs.gov/publication/ wri944135.)

Rupert, M.G., 1996, Major sources of nitrogen input and loss in the upper Snake River Basin, Idaho and western Wyoming, 1990: U.S. Geological Survey Water-Resources Investigations Report 96-4008, 15 p. (Also available at http://pubs.er.usgs.gov/publication/wri964008.)

Rupert, M.G., 1997, Nitrate $\left(\mathrm{NO}_{2}+\mathrm{NO}_{3}-\mathrm{N}\right)$ in ground water of the upper Snake River Basin, Idaho and western Wyoming, 1991-95: U.S. Geological Survey WaterResources Investigations Report 97-4174, 47 p. (Also available at http://pubs.er.usgs.gov/publication/wri974174.)

Rupert, M.G., 2003, Probability of detecting atrazine/ desethyl-atrazine and elevated concentrations of nitrate in ground water in Colorado: U.S. Geological Survey WaterResources Investigations Report 2002-4269, 35 p. (Also available at http://pubs.er.usgs.gov/publication/wri024269.)

Rupert, M.G., Stone, M.A.J., and Ott, D.S., 1996, National Water-Quality Assessment Program-Nitrate and pesticides in ground water, Blaine, Cassia, Lincoln, and Minidoka Counties, south-central Idaho: U.S. Geological Survey Fact Sheet 246-95, 4 p. (Also available at http://pubs.er.usgs.gov/ publication/fs24695.)

Rupert, M.G., and Plummer, L.N., 2009, Groundwater quality, age, and probability of contamination, Eagle River watershed valley-fill aquifer, north-central Colorado, 20062007: U.S. Geological Survey Scientific Investigations Report 2009-5082, 59 p. 
Skinner, K.D., and Donato, M.M., 2003, Probability of detecting elevated concentrations of nitrate in ground water in a six-county area of south-central Idaho: U.S. Geological Survey Water-Resources Investigations Report 2003-4143, 29 p. (Also available at http://pubs.er.usgs.gov/publication/ wri034143.)

Solley, W.B., Pierce, R.R., and Perlman, H.A., 1993, Estimated use of water in the United States in 1990: U.S. Geological Survey Circular 1081, 76 p. (Also available at http://pubs.er.usgs.gov/publication/cir1081.)

Solley, W.B., Pierce, R.R., and Perlman, H.A., 1998, Estimated use of water in the United States in 1995: U.S. Geological Survey Circular 1200, 71 p. (Also available at http://pubs.er.usgs.gov/publication/cir1200.)

SYSTAT Software, Inc., 2004, SYSTAT 11, Statistics IISoftware documentation: Richmond, Calif., SYSTAT Software, Inc., 657 p.

Thornton, P.E., Running, S.W. and White, M.A., 1997, Generating surfaces of daily meteorological variables over large regions of complex terrain: Journal of Hydrology, v. 190, iss. 3 and 4, p. 214-251.

U.S. Department of Agriculture, 2003, County boundaries of Idaho: U.S. Department of Agriculture, Natural Resources Conservation Service, accessed July 19, 2004, at http:// insideidaho.org/data/NRCS/archive/.

U.S. Department of Agriculture, 2004, National Agricultural Imagery Program (NAIP): U.S. Department of Agriculture, Farm Services Agency, Aerial Photography Field Office.

U.S. Department of Agriculture, 2008, Soil Survey Geographic (SSURGO) database: United States Department of Agriculture, Natural Resources Conservation Service database, accessed May 3, 2012, at http://soils.usda.gov/ survey/geography/ssurgo/.
U.S. Department of Agriculture, 2010, Quick Stats User Guide: U.S. Department of Agriculture, Natural Resources Conservation Service, accessed May 3, 2012, at http:// quickstats.nass.usda.gov/help.

U.S. Environmental Protection Agency, 2008, STORET/ WQX_STORET Date Warehouses: U.S. Environmental Protection Agency Web site, accessed May 3, 2012, at http://www.epa.gov/storet/dbtop.html.

U.S. Geological Survey, 2008, National Water Information System-Web Interface (USGS Water Data for the Nation): U.S Geological Survey Web site, accessed May 3, 2012, at http://waterdata.usgs.gov/nwis/.

Whitehead, R.L., 1992, Geohydrologic framework of the Snake River Plain regional aquifer system, Idaho and eastern Oregon: U.S. Geological Survey Professional Paper 1408-B, 32 p., 6 pls. (Also available at http://pubs.er.usgs. gov/publication/pp1408B.)

Young, H.W., Parliman, D.J., and Jones, M.L., 1987a, Selected water-quality data for the Burley irrigation district, southcentral Idaho, March-April, 1987: U.S. Geological Survey Open-File Report 87-240, 1 map. (Also available at http:// pubs.er.usgs.gov/publication/ofr87240.)

Young, H.W., Parliman, D.J., and O’Dell, I., 1987b, Selected water-quality data for the Minidoka Irrigation District, south-central Idaho, June 1987: U.S. Geological Survey Open-File Report 87-465, 1 map. (Also available at http:// pubs.er.usgs.gov/publication/ofr87465.) 
Publishing support provided by the U.S. Geological Survey

Publishing Network, Tacoma Publishing Service Center

For more information concerning the research in this report, contact the Director, Idaho Water Science Center

U.S. Geological Survey

230 Collins Road

Boise, Idaho 83702

http://id.water.usgs.gov

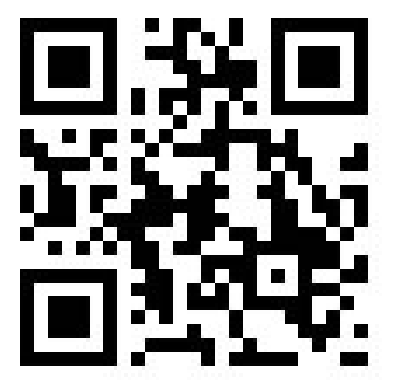




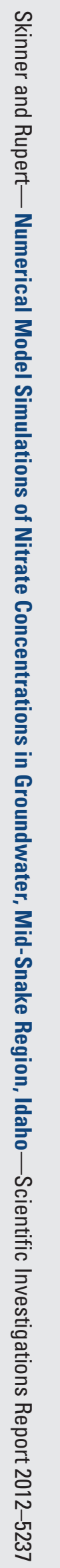

